DOI: $10.19195 / 0080-3626.61 .5$

MARIAN PTASZYK

\title{
TOMASZ UJAZDOWSKI (1796-1836) - PEDAGOG, PUBLICYSTA, WYDAWCA, „STAROŻYTNIK”, MIŁOŚNIK KSIĄŻEK I ZABYTKÓW PRZESZŁOŚCI, DZIAŁACZ POLITYCZNY
}

Biografia Ujazdowskiego. Pierwsze publikacje. Redagowanie „Pamiętnika Sandomierskiego”. Publicystyka czasu powstania listopadowego („Tandeciarz”). Redagowanie „Rozmaitości Krakowskich”. Pomnik rycerstwa polskiego z wieku XV. Prywatny księgozbiór Ujazdowskiego i kolekcjonerstwo zabytków przeszłości.

SŁOWA KLUCZOWE: Tomasz Ujazdowski, „Pamiętnik Sandomierski”, „Tandeciarz”, „Rozmaitości Krakowskie”, kolekcjonerstwo, bibliofilstwo, folklorystyka, czasopiśmiennictwo

\section{WSTĘP}

Wiedza o Tomaszu Ujazdowskim jest bardzo skromna. Kilka krótkich not biograficznych ukazało się w różnych publikacjach, od 1867 roku poczynając ${ }^{1}$. Więcej szczegółów biograficznych podał Aleksander Patkowski w 1930 roku w artykule poświęconym Ujazdowskiemu. Wykorzystał on, co prawda niezbyt liczne, dokumenty z archiwów warszawskich, ale artykuł ten ma nadal bardzo dużą wartość źródłową, wiele z tych dokumentów nie zachowało się bowiem do dzisiaj, jak np. przygotowany na polecenie władz oświatowych w 1823 roku przez Ujazdowskiego życiorys $^{2}$. Ciekawy i ważny artykuł napisała Barbara Wolska

${ }^{1}$ F.M. Sobieszczański, Ujazdowski Tomasz, [hasło w:] Encyklopedia powszechna, t. 25, Warszawa 1867, s. 951; J. Bieliński, Królewski Uniwersytet Warszawski, t. 3, Warszawa 1912, s. 466; M. Tyrowicz, Towarzystwo Demokratyczne Polskie 1832-1863. Przywódcy i kadry członkowskie. Przewodnik Biograficzny, Warszawa 1964, s. 715-716; W. Berbelicki, Ujazdowski Tomasz, [hasło w:] Materiały do Słownika publicystów i dziennikarzy polskich, „Zeszyty Prasoznawcze” 6, 1965, nr 2 (24), s. 66; R. Gerber, Studenci Uniwersytetu Warszawskiego 1808-1831. Stownik biograficzny, Wrocław 1977, s. 224.

2 A. Patkowski, Tomasz Ujazdowski, wydawca „Pamiętnika Sandomierskiego”, „Pamiętnik Świętokrzyski” 1930, s. 213-229. 
o wydawanym w czasie powstania listopadowego przez Ujazdowskiego pisemku satyrycznym „Tandeciarz”. Wiele miejsca poświęciła biografii wydawcy, czerpiąc wiadomości głównie ze wspomnianego artykułu A. Patkowskiego ${ }^{3}$. Badania proweniencyjne starych druków, prowadzone przez bibliotekarzy w Bibliotece Narodowej i Bibliotece Uniwersyteckiej w Warszawie, potwierdziły skromne wiadomości, zawarte w dotąd nieanalizowanych artykułach Ujazdowskiego opublikowanych w prasie warszawskiej, o jego pasji gromadzenia książek, głównie starych, a także innych zabytków.

Różnorodna działalność T. Ujazdowskiego, szczególnie ważna dla dziejów polskich badań nad zabytkami przeszłości, edytorstwa źródeł historycznych i czasopiśmiennictwa, w pełni uzasadnia potrzebę ponownego zajęcia się tą postacią, nie tylko przedstawienia jak najpełniejszej jej biografii, ale także ukazania wszystkich aspektów jej działalności. Ponieważ w dotychczasowych publikacjach nie poświęcono zbyt wiele miejsca najważniejszemu wydawnictwu redagowanemu przez Ujazdowskiego - „Pamiętnikowi Sandomierskiemu”, również i to zagadnienie zostało uwzględnione w niniejszym artykule.

\section{1. ŻYCIORYS}

Tomasz Ujazdowski urodził się w Wilnie 12 marca 1796 roku w szlacheckiej rodzinie. Rodzice, Domicela z Gałeckich i Ambroży Mikołaj Ujazdowski, wcześnie go odumarli ${ }^{4}$. W 1806 roku opiekun, Jakub Popławski, późniejszy podprefekt powiatu łukowskiego, umieścił go w gimnazjum prowadzonym przez księży komunistów w Węgrowie (po 1809 roku szkoła wydziałowa). Ukończył tam 5 klas (1812), a przez rok, w czasie wojny 1812-1813, przebywał u swego opiekuna, doskonaląc znajomość łaciny. W celu uzyskania materialnej niezależności postanowił zostać nauczycielem. Dlatego w następnym roku wstąpił do zgromadzenia księży pijarów w Opolu Lubelskim (śluby złożył 19 września 1815 roku). W 1815 został przeniesiony do Warszawy, gdzie nauczycielami jego byli wybitni pedagodzy pijarscy: Edward Czarnecki, Kajetan Kamieński, Jan Gwalbert Bystrzycki - matematyk, fizyk i chemik (pierwszy wykładał tę naukę jako oddzielny przedmiot), Antoni Dąbrowski — matematyk, Stefan Przeczytański — matematyk, logik, filozof, a także nauczyciel świecki z Liceum Warszawskiego — Jan Krzysztof Stöphasius, klasyk.

3 B. Wolska, Tomasz Ujazdowski, wydawca „Tandeciarza”, „Prace Polonistyczne” 31, 1975, s. $175-203$.

${ }^{4} \mathrm{O}$ innych członkach rodziny brak informacji. W liście do Jana Nepomucena Janowskiego Tomasz Ujazdowski w kwietniu 1836 roku prosił o opiekę nad jego bliskim krewnym „T. Krzyżano" przebywającym wówczas na emigracji we Francji. Może chodziło o Piotra Krzyżanowskiego, powstańca, emigranta. W powiecie siedleckim właścicielem dóbr Dziewule był Andrzej Ujazdowski, który prenumerował „Pamiętnik Sandomierski” redagowany przez Tomasza Ujazdowskiego — M. Woliński, Herbarz szlachty ziemi łukowskiej na Lubelszczyźnie, t. 2, Szczecin 2014, s. 367. 
Po zakończeniu nauki Ujazdowski zdał egzamin przed Kapitułą oraz Komisją Rządową Wyznań Religijnych i Oświecenia Publicznego (dalej: KRWRiOP) i został w 1817 roku nauczycielem w szkole wojewódzkiej księży pijarów w Radomiu, a następnie w szkole wydziałowej w Wieluniu prowadzonej przez ten sam zakon. Z końcem roku szkolnego 1818/1819 skończył mu się obowiązkowy trzyletni okres pracy w szkołach pijarskich ${ }^{5}$. Zwrócił się wówczas do swego prowincjała, ks. Kajetana Kamieńskiego, o zgodę na starania o unieważnienie ślubów zakonnych. Zgodę otrzymał i rozpoczął się proces w konsystorzu w Kaliszu, kontynuowany następnie w konsystorzu w Warszawie. Jeszcze w czasie pracy w Wieluniu zdał odpowiedni egzamin i od 1 września 1819 do 21 czerwca roku następnego był guwernerem w korpusie kadetów w Kaliszu, skąd został zwolniony z powodu zmian w programie nauczania. Po opuszczeniu Kalisza 23 października 1820 roku Ujazdowski zapisał się na Wydział Prawa Uniwersytetu Warszawskiego. Równocześnie był aplikantem w Prokuraturze Generalnej. Z powodu braku środków przeniósł się do Krakowa, gdzie zdał wszystkie egzaminy i dnia 29 października 1821 roku zapisał się na drugi rok studiów na Wydziale Prawa Uniwersytetu Jagiellońskiego. Przerwał studia, gdy ogłoszono postanowienie cara Aleksandra I z dnia 9 kwietnia 1822 roku, które wprowadzało dla mieszkańców Królestwa Polskiego obowiązek posiadania pozwolenia rządu na naukę za granicą. Bez tego dokumentu absolwenci szkół zagranicznych nie mogli pełnić funkcji publicznych w Królestwie Polskim ${ }^{6}$. Po zdaniu wszystkich egzaminów obowiązujących na drugim roku prawa i na wykładach z literatur klasycznych wrócił do Królestwa, gdzie 16 września 1822 roku otrzymał nominację na zastępcę nauczyciela w szkole wojewódzkiej w Kielcach. Od tej chwili zaczął się dla Ujazdowskiego okres stabilizacji. Dnia 20 kwietnia 1823 roku zapisano go w Księdze Gminnej Obywatelskiej Okręgu Kieleckiego, co dawało mu prawo do zajmowania stanowisk będących w dyspozycji rządu ${ }^{7}$. W tym też roku ożenił się z Józefą Skupińską ${ }^{8}$. Obok pracy w szkole i udzielania prywatnych lekcji zamierzał Ujazdowski otworzyć w Kielcach antykwariat, na co mu władze nie dały zezwolenia, aby nie konkurował z działającym już wówczas w tym mieście księgarzem ${ }^{9}$. Starania o zezwolenie na otwarcie antykwariatu w Kielcach poparł oświadczeniem, że ,już materiały do tego przysposobił”. Jak wyjaśniał w 1826 roku w piśmie do KRWRiOP, „starał

5 W swym życiorysie dla KRWRiOP w 1823 roku napisał, że zgodnie z przepisami wprowadzonymi w Księstwie Warszawskim był zobowiązany za każdy rok nauki w seminarium pijarskim odpracować trzy lata w szkołach prowadzonych przez ten zakon - zob. A. Patkowski, op. cit., s. $213-214,220$.

${ }^{6}$ Osoby studiujące bez zezwolenia powinny były je uzyskać lub wrócić do Królestwa w ciągu roku, licząc od 1 września 1822 roku — „Dziennik Praw [Królestwa Polskiego]” 7, 1822, s. 361 364. A. Patkowski, op. cit., s. 213-214, 228.

7 Zapis w księdze obywatelskiej obowiązywał szlachtę.

${ }^{8}$ Ujazdowscy mieli troje dzieci; pierwsze urodziło się w 1824 roku - A. Patkowski, op. cit., s. $214-216$.

9 C. Erber, Książki na Kielecczyźnie w latach 1795-1865, Kielce 1996, s. 10, 108-109. 
się nagromadzić materiałów ściągających się do literatury ojczystej, wykrył kilku rodaków dzieła $\mathrm{z}$ wieku $\mathrm{XV}$, dotąd nieznanych, z dzieł zaś drukowanych w różnych drukarniach polskich po zaprowadzeniu onych do kraju wiele posiada rzeczy, które mało albo cale nie [są] naszym bibliografom znane [...] z czego wszystkiego da obszerne objaśnienia w pismach publicznych krajowych w roku bieżącym"10.

Te zainteresowania dawnym piśmiennictwem i zabytkami przeszłości wiązały się z licznymi podróżami Ujazdowskiego, które — jak wynika z lektury jego pism - przed 1830 rokiem odbył nie tylko do miejscowości, w których się kształcił lub był nauczycielem. W Kaliszu 24 lipca 1820 roku w klasztorze reformatów, według kronikarza zakonu, „oglądał obrazy konwersa naszego, fratra Bonifacjusza i ołtarze roboty snycerski[ej] bardzo wdzięczne [...] a w kościele oglądał obrazy przed SS[anctissi]-mum nie klękając". Chciał w tym klasztorze zamieszkać (był wówczas nauczycielem w Kaliszu), ale mu odmówiono ${ }^{11}$. Przynajmniej dwa razy, w 1816 i 1819 roku, odwiedził Podlasie, a właściwie pogranicze mazowiecko-podlaskie (między Siedlcami i Węgrowem), skąd prawdopodobnie wywodziła się jego rodzina. Pokłosiem tych wojaży były szkice historyczne o wsiach Budzieszyn, Mokobody, Pniewnik, Wierzbno, Lipki, Maliszowa i Trawy oraz o ówczesnym miasteczku Liw ${ }^{12}$. W czasie nauki w klasztorze w Opolu Lubelskim poznał tamtejszą bibliotekę klasztorną i księgozbiór oraz inne zbiory po Zofii z Krasińskich Lubomirskiej zgromadzone w miejscowym pałacu. W czasie studiów w Krakowie z pewnością był czytelnikiem w Bibliotece Uniwersyteckiej, a w czasie zwiedzania klasztoru franciszkanów zapoznał się z ich biblioteką, oceniając, że „od lat 50 i jedna się nowa księga do niej nie wcisnęła" ${ }^{3}$. Tam zainteresował się Franciszkiem Jabłońskim, autorem pozostających w rękopisie Herbów rycerstwa Polskiego, i odwiedził wszystkie klasztory, w których ten XVII-wieczny franciszkanin przebywał: Warszawę, Lwów, Poznań, Lelów ${ }^{14}$ i Korczyn ${ }^{15}$. Czasem nadkładał drogi, aby zwiedzić nieznane miejsca. W grudniu 1826 roku z Kielc do Kalisza je-

10 Cyt. za: A. Patkowski, op. cit., s. 217.

11 Ibidem, s. 214.

$12 \mathrm{~W}$ pierwszym tomie wydawanego przez T. Ujazdowskiego „Pamiętnika Sandomierskiego" znajdują się: Wieś Budzieszyn albo Zbudeszyno w ziemi drohickiej (s. 364-368), Wiadomość o kościołach w Liwie, Pniewniku, Wierzbnie w ziemi liwskiej, Xięstwie Mazowieckiem położonych (artykuł zawiera wypis dokumentu sporządzony na probostwie w Wierzbnie, s. 371-378), Trzystuletnia sprawa (o sporze dwu wsi: Lipki i Maliszowa, który ciągnął się od 1494 roku, s. 416-417). Wydaje się, że dwie ostatnie miejscowości były mu bardzo bliskie, bo w redagowanych przez siebie w 1834 roku „Rozmaitościach Krakowskich” zamieścił artykuł Wieś Lipki (nr 5, s. 38-40; nr 7, s. 53), w którym podał sporo szczegółów na temat życia i zwyczajów tamtejszej szlachty. Bohaterowie Przypadków pana Golenia pochodzą ze wsi Trawy („Tandeciarz” 1831, nr 10, s. 81).

13 T. Ujazdowski, Życie i pisma Franciszka Jabłońskiego zakonu braci mniejszych Ś. Franciszka, „Pamiętnik Sandomierski” 1, 1829, s. 239.

${ }^{14}$ Klasztor franciszkanów w Lelowie uległ likwidacji w 1819 roku.

15 T. Ujazdowski, Życie i pisma Franciszka Jabłońskiego..., s. 237-249. Rękopis Herbów rycerstwa polskiego Ujazdowski sprowadził ze Śląska i opublikował (ibidem, s. 249-345). 
chał przez Secymin, gdzie zwiedził kościół, a następnie klasztor św. Anny k. Przyrowu i Wyczerpy ${ }^{16}$. W tej ostatniej miejscowości stanął na nocleg. Gdy mieszkał w Kielcach, zwiedzał też okolice. Celem podróży Ujazdowskiego było poznawanie zabytków, ale nie tylko. Jak napisał w artykule opublikowanym w 1830 roku: „Przypadek zdarzył, iż w r[oku] z[eszłym] w miesiącu sierpniu w przejeździe do Wiednia przy przeglądaniu Biblioteki Pojezuickiej w Cieszynie wpadła mi w ręce książka, pod której ostatnią okładziną znalazłem pieśń rycerską zaczynającą się: Piękne jest koło Rycerskie itd. tu w końcu wieku XVI wpisaną. Książką tą jest Historya Herodota, przekład łaciński, drukowana w Frankfurcie r. 1584 w 8ce" 17 .

Rektor kieleckiej szkoły Andrzej Polejowski ${ }^{18}$ początkowo przychylnie traktował Ujazdowskiego. Po pierwszym roku pracy wyjednał mu nagrodę $390 \mathrm{zł,}$ jednak w następnym roku miał już zastrzeżenia do nowego nauczyciela, które w latach następnych pogłębiały się. W 1826 roku przekazał KRWRiOP w Warszawie taką ocenę pracy Ujazdowskiego: „Nauczyciel ten bez korzyści dla uczniów pracuje, a dla swych dziwactw i charakteru mściwego powszechnie od nich znienawidzony. Wykładając historią, wdaje się w materię duchowieństwo i moralność obrażające; w praktyce religijnej żadnego dla uczniów dobrego przykładu nie daje; nie mając dostatecznego wynagrodzenia i poszukując go z prywatnych lekcyj, opuszczał się w obowiązkach, a przestrzegany odpowiadał pogróżkami"19. Ujazdowski otrzymał od Komisji Rządowej ostrzeżenie, od którego złożył odwołanie. Następnie pismem z dnia 18 sierpnia 1826 roku Komisja zawiadomiła go o przeniesieniu do pracy w szkole wojewódzkiej w Kaliszu.

Szkoła wojewódzka w Kaliszu w tym czasie była w bardzo trudnej sytuacji, a to z powodu gorszących awantur z uczniami, które prowokował nauczyciel matematyki, Kazimierz Nahajewicz. Wywoływały one protesty mieszkańców Kalisza i miejscowych władz. Urzędujący od marca 1826 roku nowy rektor szkoły, Antoni Wolicki, pijar, energicznie przywracał porządek w szkole. Czynił to jednak bardzo arbitralnie. Gdy w październiku tego roku uczniowie zorganizowali Towarzystwo Literackie, uznał je za tajną organizację. W grudniu ,z powodu zamieszań w Szkole Wojewódzkiej Kaliskiej, na miejscowe wypadki i na odnawiane tylokrotnie

16 T[omasz] U[jazdowski], O kościele w mieście Secyminie i Klasztorze Ś. Anny pod Przyrowem..., s. 41. Wyczerpy są obecnie przedmieściem Częstochowy.

17 T. Ujazdowski, Pieśń starożytna rycerska, „Pamiętnik Sandomierski” 2, 1830, s. 109. Herodotus, Herodoti Halicarnassei Historiae libri IX: et de vita Homeri libellus. Illi ex interpretatione Laurentio Vallae adscripta [...], Francofurti 1584.

18 Andrzej Polejowski, imię zakonne: Kasper (1776-1849), pijar, w latach 1819-1833 rektor szkoły wojewódzkiej w Kielcach, surowy wobec uczniów i nauczycieli, z którymi miał częste zatargi, lojalny wobec władz w Warszawie, nie miał poparcia prezesa Komisji Wojewódzkiej w Kielcach Kaspra Wielogłowskiego - A. Massalski, Polejowski Andrzej, [w:] Polski Słownik Biograficzny, t. 27, Wrocław 1983, s. 286.

19 A. Patkowski, op. cit., s. 216-217. Decyzję o przeniesieniu najstarszych klas do Piotrkowa Trybunalskiego podjęła Rada Administracyjna Królestwa Polskiego 16 grudnia 1826 roku. 
tamże stowarzyszenia” władze centralne postanowiły zaradzić ,złemu i samowolności", przenosząc od nowego roku szkolnego dwie wyższe klasy do Piotrkowa. T. Ujazdowski starał się nie angażować w te awantury i nie podpisał deklaracji złożonej prezesowi Komisji Wojewódzkiej 22 stycznia 1827 roku przez zespół nauczycielski. Uzyskał, co prawda, w grudniu 1826 roku pozytywną ocenę kuratora szkół wyższych województwa kaliskiego, Feliksa Jerzmanowskiego („Zastępca profesora, dający jeografią i historią naturalną: punktualny jest w obowiązkach, uczęszczając regularnie do klas i kościoła; nadto spokojnym jest i gorliwym”), ale rektor A. Wolicki napisał o nim: „Ujazdowski Tomasz, lat 30. Miejsce ostatniego pobytu: Kielce. Zdatność w nauczaniu mała, pilność mała. Obrządki religijne odbywa. Konduita najlepsza. Względem zwierzchności powierzchownie. Nie złożył dowodów służby"20.

Prawdopodobnie żona Ujazdowskiego mieszkała z dziećmi nadal w Kielcach, 16 grudnia 1826 roku wyjechał on bowiem do Kielc na święta Bożego Narodzenia i wrócił po czterech tygodniach, usprawiedliwiając spóźnienie „słabością zdrowia"21. Tę podróż wykorzystał na poznawanie nowych zabytków, o czym dowodnie świadczy artykuł O kościele w Secyminie i Klasztorze Ś. Anny pod Przyrowem, napisany 27 grudnia w Wyczerpach. Można przypuszczać, że w czasie tej podróży poznał też Jasną Górę, bo czasu miał dość — do pracy w Kaliszu stawił się 14 stycznia 1827 roku.

W czerwcu 1827 roku generalny dyrektor wychowania publicznego w KRWRiOP, Józef Kalasanty Szaniawski, dowiedział się o złożonych w 1815 roku przez Ujazdowskiego ślubach zakonnych, w związku z czym 30 lipca uwolnił go „od obowiązków nauczycielskich na mocy raportów urzędowych”. W odpowiedzi na prośbę o wyjaśnienie tej decyzji Ujazdowski otrzymał pismo podpisane przez ministra Stanisława Grabowskiego z dnia 20 sierpnia 1827 roku, w którym napisano, że „zarzuty wspomniane doszły Komis[ji] Rz[ądowej] z źródła pewnego”,

nie te jednak były zasadą udzielonego mu od obowiązków uwolnienia, lecz urzędowa wiadomość jako podawca po odbytym nowicjacie u XX. Pijarów w Opolu [Lubelskim], tamże na dniu 19 września 1815 roku profesją solenną uczynił i potem lat 4 jeszcze w zgromadzeniu zostawał, a później porzuciwszy to zgromadzenie, żonę nawet pojął. Jakoż kto zgwałcił raz uroczystą przysięgę, - kto nie dotrzymał potwierdzonych nią ślubów, nie powinien być cierpianym w zawodzie publicznych urzędowań, bo żadnej już nie daje rękojmi, iż wiernym będzie przysiędze homagialnej, która obok wierności monarsze, wkłada na niego świętą powinność dopełnienia z sumiennością przyjętych na siebie obowiązków.

W odpowiedzi Ujazdowski pisemnie przedstawił ministrowi Grabowskiemu (27 sierpnia) stan starań o unieważnienie ślubów zakonnych. Biskup kujawsko-kaliski, Józef Koźmian, wystąpił w jego obronie (25 sierpnia), zapewniając KRWRiOP, że nie z winy Ujazdowskiego nie zakończono procesu unieważniające-

20 Ibidem, s. 219.

21 Ibidem, s. 216-220. 
go jego śluby zakonne, i prosił o pozostawienie go „na posadzie nauczycielskiej”. Dodatkowo o opinię poproszono rektora Andrzeja Polejowskiego z Kielc, który 9 września potwierdził swe poprzednie opinie i dodał obszerne uwagi o mało gorliwym wypełnianiu obowiązków religijnych przez Ujazdowskiego. Sprawa jego uwolnienia od ślubów zakonnych powoli zaczęła być załatwiana. W 1828 roku KRWRiOP akta przekazane jej przez biskupa J. Koźmiana przesłała do Rady Administracyjnej Królestwa Polskiego w celu wysłania ich do Rzymu. Niemniej Ujazdowski nie otrzymał już pracy w szkole, chociaż chciał wrócić do Kielc lub przenieść się do Pińczowa ${ }^{22}$.

W tej sytuacji postanowił szukać zatrudnienia w Warszawie, gdzie zamieszkał w pałacu Wincentego Krasińskiego na Krakowskim Przedmieściu obok klasztoru misjonarzy. Na początku listopada zgłosił się do Samuela Bogumiła Lindego, dyrektora Biblioteki Publicznej przy Uniwersytecie Warszawskim, z prośbą o zatrudnienie w kierowanej przez niego placówce. Dyrektor Biblioteki w piśmie do KRWRiOP podkreślił jego „zasługi w stanie nauczycielskim” i zdolności do pracy naukowej, gdyż „przez kilka drukiem ogłoszonych artykułów dał poznać skłonność swoją do prac bibliograficznych" 23 . Z początkiem stycznia następnego roku Ujazdowski został dietariuszem Biblioteki Publicznej. O jego pracy w bibliotece nie wiemy zbyt dużo. W zachowanych aktach dotyczących Biblioteki Publicznej brak nawet śladu jego starań o zgodę na wyjazd do Wiednia, a taką podróż odbył w sierpniu 1829 roku $^{24}$. Od lipca 1830 roku Ujazdowski zaczął bardzo zaniedbywać swe obowiązki w bibliotece. W tym też miesiącu wystąpił drogą służbową do najwyższych władz Królestwa Polskiego o zgodę na trzymiesięczną podróż do Austrii i Prus ,celem zwiedzenia niektórych znakomitych zagranicznych bibliotek we względzie naukowym”. Rada Administracyjna wyraziła zgodę na wyjazd, ale odmówiła mu wypłaty na ten cel trzymiesięcznej pensji, natomiast KRWRiOP udzieliła mu pomocy w wysokości 500 złp. ${ }^{25}$ Wyjechał z Warszawy na początku września i wrócił ok. 10 grudnia 1830 roku. W artykule zamieszczonym w „Gazecie Polskiej” 17 grudnia pisał o przychylności Ślązaków wobec Polaków: „Mówię to z przekonania, gdyż w roku bieżącym cały Śląsk zwiedziłem, miasta Brzeg, Opole i Wrocław najprzyjemniejszy mi widok i uczucie sprawiły". O bibliotekach nie napisał ani słowa ${ }^{26}$. Podróż Ujazdowskiego przypadła w czasie, gdy sprzysiężenie Piotra Wysockiego wysyłało swych emisariuszy do trzech zaborów.

22 Ibidem, s. 220-221.

${ }^{23}$ Cyt za: ibidem, s. 221.

24 Bibliotekarze byli zobowiązani uzyskać zgodę Rady Administracyjnej Królestwa Polskiego.

25 M. Łodyński, Materiaty do dziejów państwowej polityki bibliotecznej w Księstwie Warszawskim i Królestwie Polskim (1807-1831), Wrocław 1958, s. 162, 192, 289-292.

26 T. Ujazdowski, Sprawa ich jest łaczna z nasza, „Gazeta Polska” 1830, nr 334; przedruk [w:] Polskie podróże po Śląsku w XVIII i XIX wieku (do 1863 r.), wybrał i oprac. A. Zieliński, Wrocław 1974, s. 159-161. 
Czy Ujazdowski tej funkcji się podjął, nie wiadomo, chociaż wspomniany wyżej artykuł zdaje się taką misję potwierdzać ${ }^{27}$. Nie była to pierwsza podróż Ujazdowskiego na Śląsk. Był tam już przed 1829 rokiem i nabył rękopis Kazimierza Malinowskiego. Stamtąd sprowadzał też książki.

Ze Śląska wracał przez Kraków, gdzie obserwował duże zainteresowanie napisaną przez Jana Nepomucena Janowskiego odezwą pt. Do obywateli Rzeczypospolitej Krakowskiej ${ }^{28}$. Do pracy w Bibliotece Publicznej już nie wrócił nie załatwił związanych z tym formalności urzędowych. Nieznane jest źródło utrzymania Ujazdowskiego i jego rodziny w tamtym czasie. Być może współpracował z którąś z warszawskich gazet, np. z „Gazetą Polską", która przez cały czas powstania popularyzowała kolejne numery wydawanego przez niego „Tandeciarza”. Zdaje się świadczyć o tym fakt, że w „Gazecie Polskiej” ukazywały się doniesienia prasowe podobne do tych zamieszczanych w „Tandeciarzu”. Na jej łamach ukazał się też niewielki artykuł Ujazdowskiego o straceniu zdrajcy Rafała Cichockiego. Ujazdowski — jak określał go A. Patkowski — „gorący zwolennik radykalnego obozu »Gazety Polskiej«"29 zaangażował się wówczas w działalność polityczną: w dniu 19 stycznia 1831 roku w czasie organizacyjnego zebrania Towarzystwa Patriotycznego został jego członkiem. W czerwcu wybrano go do Rady Towarzystwa, a w lipcu, gdy organizacja Towarzystwa rozluźniła się, został jego sekretarzem - wydaje się, że funkcję tę oprócz niego pełnili też różni członkowie Rady $^{30}$. Prawdopodobnie uczestniczył w dyskusjach na zebraniach Towarzystwa, ale w prasowych sprawozdaniach nie odnotowano jego wystąpień. Sądząc po jego ówczesnych publikacjach — reprezentował bardzo radykalne poglądy społeczne. 22 stycznia 1831 roku złożył swój podpis pod dokumentem w sprawie Litwy i Ukrainy („Tomasz Ujazdowski z Litwy”), który Joachim Lelewel przedstawił sejmowi na sesji 24 stycznia. Podpisał się także pod innym dokumentem (Zdanie sprawy przez Braci Zjednoczonych) w tej samej sprawie — „Ujazdowski Tomasz (Litwa)". Na sejmiku województwa wileńskiego 6 sierpnia w Warszawie kandydował na posła do sejmu — otrzymał jeden głos ${ }^{31}$.

27 M. Łodyński, op. cit., s. 192, 289, 293; W. Tokarz, Sprzysiężenie Wysockiego i noc listopadowa, oprac. A. Zahorski, Warszawa 1980, s. 89.

28 „Kurier Polski” 1830, nr 356 (9 grudnia); J.N. Janowski, Notatki autobiograficzne 18031853, przygotował do druku, wstępem i przypisami opatrzył M. Tyrowicz, Wrocław 1953, s. 168 169.

29 A. Patkowski, op. cit., s. 224.

30 W. Smoleński, Towarzystwo patriotyczne, „Przegląd Historyczny” 8, 1909, s. 103. T. Ujazdowski jako sekretarz podpisał 21 lipca apel Towarzystwa o sprawiedliwe postępowanie przy poborze koni na potrzeby wojska — zob. Towarzystwo Patriotyczne Warszawskie, „Gazeta Polska” 1831, nr 196, s. 3.

31 Dyariusz sejmu z r. 1830 i 1831, wyd. M. Rostworowski. T. 1, Od 18 grudnia 1830 do 8 lutego 1831, Kraków 1907, s. 172; Zdanie sprawy przez Braci Zjednoczonych z tego, co w celu oswobodzenia Litwy, Wotynia, Podola, Ukrainy w przeciagu czterech miesięcy od dnia rewolucji 29 listopada na wolnej ziemi polskiej działano, Warszawa 1831; A. Patkowski, op. cit., s. 226. 
Nie wiadomo, kiedy wstąpił do Gwardii Narodowej, ale 5 września 1831 roku „Gazeta Polska” zamieściła jego notatkę: „Upraszam Redakcyi o uczynienie w piśmie jej zapytanie: czy do wyboru dowódzcy [!] Gwar[dii] Nar[odowej] mają należeć wszyscy członkowie tej instytucyi, czyli też tylko pewne indywidua? Do zaniesienia tej prośby powoduje mnie ostatni wybór, przez wielu bardzo gwardzistów uważany za nielegalny. T.U.”

Po upadku powstania T. Ujazdowski przeniósł się z rodziną do Krakowa, gdzie utrzymywał kontakty z Ludwikiem Królikowskim, który za zgodą uniwersytetu prowadził pensjonat dla studentów i licealistów. Możliwe, że zatrudnił on Ujazdowskiego, z którym mógł się zaprzyjaźnić w Kielcach, gdzie uczył się do 1823 roku, lub w czasie krótkiego pobytu w Warszawie (czerwiec-początek sierpnia 1831), gdy działał w lewicy Towarzystwa Patriotycznego. W Krakowie obaj zaangażowali się w działalność konspiracyjną. Ujazdowski był członkiem i prawdopodobnie pełnomocnikiem Centralizacji Towarzystwa Demokratycznego. Korespondował z przywódcą Towarzystwa Demokratycznego Polskiego Janem Nepomucenem Janowskim, któremu tuż przed opuszczeniem Krakowa załatwiał jakieś przesyłki. Możliwe, że w związku z pracą konspiracyjną odbył przynajmniej dwie podróże po Galicji, które nazywał „podróżami naukowymi”: pierwszą w 1832 lub w roku następnym po Sądecczyźnie, a drugą w $1835^{32}$.

Autor nekrologu napisanego po śmierci Ujazdowskiego tak wyraził się o tej jego działalności: „Po rewolucji [tj. powstaniu listopadowym] potrafił Ujazdowski zostać w Krakowie, a wierny świętej sprawie ludu polskiego krzewił w miarę możności zasady rewolucyjne, które prędzej czy później Ojczyznę dźwignąć muszą". Sytuacja Ujazdowskiego i innych emigrantów z Królestwa Polskiego zaczęła się pogarszać, gdy Austriacy i pozostali zaborcy przystąpili do stopniowego oczyszczania Rzeczypospolitej Krakowskiej z ludzi przybyłych z Królestwa Polskiego po powstaniu i zaangażowanych w działalność patriotyczną. Decydujące działania w tym względzie wojska trzech państw zaborczych przeprowadziły po 17 lutego 1836 roku $^{33}$. Wśród wysiedlonych z Krakowa znalazł się też Ujazdowski, który wcześniej, bo 15-16 lutego, razem z innymi uchodźcami z Królestwa Polskiego przeniósł się z Krakowa na pobliskie Podgórze ${ }^{34}$. Został on w kwietniu

Prawdopodobnie wybór posłów odbył się 6 sierpnia 1831 roku — „Gazeta Polska” 1831, nr 211 (7 sierpnia), nr 216 (12 sierpnia).

32 O tych podróżach świadczą dwie wiadomości w „Rozmaitościach Krakowskich”: o dzwonie kościelnym w Podegrodziu k. Sącza i płycie nagrobnej Fausta Socyna w Lusławicach w powiecie tarnowskim (nr 13, s. 104) oraz wymienione miejscowości w broszurze T. Ujazdowskiego Pomnik rycerstwa polskiego z wieku XV odkryty przez Tomasza Ujazdowskiego, niegdyś wydawce „Pamiętnika Sandomierskiego", Kraków 1835.

33 „Gazeta Krakowska” 16 kwietnia 1836 roku poinformowała, że część wojska austriackiego opuściła Kraków.

34 Podgórze - dzisiaj część prawobrzeżna Krakowa, wówczas miasteczko nienależące do Rzeczypospolitej Krakowskiej. 
tego roku wywieziony wraz z rodziną do Triestu (9 kwietnia 1836 informował J.N. Janowskiego: „15 kwietnia jadę do Triestu”), skąd miał być deportowany do Ameryki ${ }^{35}$. W nekrologu napisanym cztery tygodnie po jego śmierci czytamy: „Po zajęciu Krakowa uległ spólnemu wszystkim rewolucjonistom losowi i wraz z żoną i trojgiem dzieci do Triestu wywiezionym został" 36 . Do wyjazdu do Ameryki jednak już nie doszło, w Trieście bowiem zachorował na cholerę i zmarł tam 1 października 1836 roku.

\section{POCZĄTKI DZIAŁALNOŚCI PUBLIKACYJNEJ I REDAKCJA „PAMIĘTNIKA SANDOMIERSKIEGO”}

W maju 1826 roku zaczął Ujazdowski publikować swoje teksty na łamach prasy warszawskiej, informując czytelników „Monitora Warszawskiego”: „Trudniąc się od lat kilku zbieraniem pamiątek narodowych przypadkiem wpadło mi w ręce kilka medalów..."37 Odtąd na łamach warszawskiej prasy do końca 1828 roku ukazało się sześć jego artykułów, z których czytelnicy poznawali rozległość zainteresowań ich autora. Ze wspomnianych wyżej „medalów”, które pozyskał, uznał za ważne dwa rzymskie, Hadriana i Antoniusza, oraz jeden polski z XVI wieku znaleziony w 1822 roku pod budynkiem kolegiaty w Skalbmierzu. W Wyczerpach, 27 grudnia $1826 \mathrm{roku}$, napisał relację ze zwiedzania kościoła w Secyminie. Zainteresowało go w nim epitafium Jana Brocha i kamienna rzeźba („,dwie ręce wielkości naturalnej leżące na mieczu obosiecznym”) wmurowana w ceglaną ścianę na zewnątrz budowli. Starał się uzyskać od proboszcza i innych osób wyjaśnienie znaczenia rzeźby i okoliczności jej powstania, ale udzielone mu odpowiedzi nie przekonywały go. O mieście i jego historii dowiedział się prawdopodobnie wcześniej, może z lektury. W XVI i na początku XVII wieku w Seceminie działała luterańska szkoła. „Uczyło w niej kilku akademików krakowskich sławnych w owym czasie. Lecz to wszystko znikło"38. W tej podróży z Kielc do Kalisza jeszcze krótko odwiedził klasztor bernardynów św. Anny pod Przyrowem. Dwadzieścia dni później ukazał się kolejny artykuł, w którym Ujazdowski chwalił się: „W roku zeszłym nabyłem kilkadziesiąt książek w języku łacińskim”. Dalej informował,

35 Od 1831 roku polskich uchodźców z Królestwa Polskiego, którym nie dawano paszportu do Francji lub Anglii, deportowano z portu w Trieście do Maroka, Algierii, Egiptu i Ameryki.

36 Informacje o ostatnim roku życia T. Ujazdowskiego na podstawie: Pomnik rycerstwa...; Laboramus, ,Rzeczpospolita Polska, federacyjna, demokratyczna, socyalna w śród stanów zjednoczonych słowiańskich i ludzkości” (Genève) 1870, nr 10, s. 74; A. Patkowski, op. cit., s. 227; J. Turowski, Utopia społeczna Ludwika Królikowskiego, Warszawa 1958, s. 100-101, 107-108.

37 T. Ujazdowski, Medale nowo w województwie krakowskiem znalezione, „Monitor Warszawski" 1826, dodatek do numeru 63, s. 289.

38 Idem, O kościele w mieście Secyminie i Klasztorze Ś. Anny pod Przyrowem, „Monitor Warszawski" 1827, nr 9, s. 41. 
że ok. 1590 roku sprowadził je do swojej biblioteki „Jacek czyli też Jakob Ponentowski i kazał oprawiać w Krzepicach". W oprawie jednej z tych książek, Aristoteli Politicorum libri octo. Theodor Zwingeri argumentis [...] illustrati (Basileae 1582), Ujazdowski znalazł polskie karty do gry z XVI wieku. W tym też artykule, w którym informował o tym znalezisku, zamieścił fragment kazania Gabriela Leopolity z początku XVII wieku, poświęconego zgubnym skutkom gry w karty (Oratorium Pałaczu Duchownego, Lwów 1619) ${ }^{39}$.

W relacji z Kalisza, 26 lutego 1827 roku, doniósł o znalezionych w kościele św. Mikołaja w Kaliszu dwóch płaskorzeźbach, prawdopodobnie z XV wieku. Jedna wzbudziła jego szczególne zainteresowanie, przedstawiała bowiem moment egzekucji za pomocą gilotyny. W napisanym wówczas artykule Rzecz o guillotynie Ujazdowski przedstawił historię tego przedmiotu — podobno sięgającą czasów starożytnej Persji. Jest to popis erudycji. Z satysfakcją w oparciu o posiadaną rycinę z nieznanej sobie książki prostował wiadomość, jakoby w 1268 roku na gilotynie mieli zginąć Konradyn Szwabski (król Jerozolimy i Sycylii, 1252-1268) i Fryderyk książę austriacki (1249-1268). Ponieważ rzeźba znajdowała się w kościele po kanonikach laterańskich, powołał się na swoją znajomość średniowiecznych kościołów tego zakonu, we względzie „snycerskiej roboty”, w Krzyńcach (raczej w Krzepicach), Kłobucku, Mstowie, Warszawie i Krakowie. Dalej podał dokładny opis kaliskiego zabytku i jego oddzielenia od ławki, której był nieodłączną częścią. Informował ponadto, że płaskorzeźby wyjęto z oparcia ławek i wykonano gipsowe odlewy. Oryginały przesłano do Puław, a odlewy do Warszawy do Towarzystwa Przyjaciół Nauk ${ }^{40}$.

Po roku, 13 maja 1828 roku, Ujazdowski napisał w Warszawie krótki artykuł, do którego pretekstem był uczyniony przez Jana Smarzewskiego na rzecz Towarzystwa Przyjaciół Nauk dar siekierki kamiennej. Ujazdowski objaśnił, poprawnie z punktu widzenia obecnej wiedzy archeologicznej, budowę siekierki kamiennej pochodzącej ze zbiorów Kazimierza Cywińskiego ${ }^{41}$. W kolejnym artykule z 1828 roku odświeżał w pamięci Polaków bitwy z Turcją pod Warną i pod Chocimiem, odbyte tego samego dnia — 11 listopada: pierwszą zakończoną klęską i śmiercią polskiego i węgierskiego króla, Władysława, i drugą zakończoną świetnym zwycięstwem hetmana Jana Sobieskiego ${ }^{42}$.

W latach 1829-1830 Ujazdowski wydawał w Warszawie kwartalnik „Pamiętnik Sandomierski. Pismo poświęcone dziejom i literaturze oyczystey”. Nie

39 Idem, Karty polskie do grania, „Monitor Warszawski” 1827, nr 18, s. 87-88.

40 Idem, Rzecz o guillotynie znanej w Polsce wedlug rzeźby w kościele w Kaliszu, ,Rozmaitości Warszawskie” (dodatek tygodniowy do „Gazety Korespondenta Warszawskiego i Zagranicznego") 1827, nr 15, s. 113-116; A. Patkowski, op. cit., s. 219.

41 T. Ujazdowski, Siekierka kamienna, „Gazeta Polska” 1828, nr 136, s. 511-512. Por. też Archiwum Główne Akt Dawnych, Towarzystwo Przyjaciół Nauk (dalej: AGAD, TPN), sygn. 93, s. 24.

42 Idem, Wspomnienie Narodowe, „Gazeta Polska” 1828, nr 307, s. 1225. 
zapowiedział go wcześniej żadnym prospektem. Dopiero 13 lutego, tuż przed ukazaniem się pierwszego zeszytu, w prasie warszawskiej zamieścił anonimowe ogłoszenie: „Z drukarni XX. Pijarów wkrótce wyjdzie Pamiętnika Sandomierskiego pierwszy poszyt, cztery takowych składać będą tom”. Podał też jego zawartość w postaci spisu treści i zakończył informacją: „Życzący to pismo mieć, raczy się wcześniej zapisać, a przy odbieraniu poszytu zapłaci, który w Warszawie złotych trzy kosztować będzie". O ukazaniu się pierwszego poszytu informowano 13 marca, a drugiego - $30 \mathrm{kwietnia}^{43}$. Dopiero w połowie listopada, po ukazaniu się czwartego poszytu, Ujazdowski opublikował w prasie Prospekt na pismo czasowe pamiętnik sandomierski, w którym pisał: „Pismo to, jak czytelnikom wiadomo, wychodziło już w roku bieżącym i cztery poszyty składające tom pierwszy przedpłacającym doręczone zostały. Żem przed wyjściem rzeczonego tomu nie ogłosił prospektu, ta była przyczyna, iż chciałem się wprzód zapewnić, z jakim duchem przyjęty będzie; nie polecałem go publiczności, lecz chciałem, ażeby ona sama oceniła wartość i uznała jego potrzebę". Dalej przedstawił program swego wydawnictwa:

Umiejący rzeczy brać z gruntu, wiedzą, ile każdemu narodowi zależy na pielęgnowaniu języka i pamiątek swoich. Dzięki światłym wydawcom przedniejszych pisarzy narodowych nie zaginą już obszerniejsze naukowe dzieła pojedynczych osób i czyny dzielnych części lub całego rodu ziomków; lecz jeszcze zostaje wiele pomniejszych istotnych pisemek, choć drukowanych, ale bardzo rzadkich lub w rękopisach łatwo zepsuciu podpadających, które tylko są wyłączną własnością swych miłośników, a które nieraz nader ważne dla języka i historii ojczystej zawierają przedmioty. Tą powodowany uwagą, wziąłem się do wydawania pisma, o którem mowa. Podobnie jak dotąd opisywać będę sławne lub pominione w dziejach naszych miasta, wsi, rzeki, jeziora, góry, kościoły, nagrobki, mogiły, posągi, zamki, pobojowiska it.p. Będę wydobywać z ukrycia rękopisma, przenosił na papier dzisiejsze ustne podania, mało lub wcale nieznane obyczaje i śpiewy ludu naszego z historją mające związek i nieraz jej wątpliwości wyjaśniające. Życia znakomitych mężów, bez względu na stan i urodzenie, którzy krwi własnej i majątku w potrzebach ojczyzny nie szczędzili, i tych, którzy mądrą radą w pokoju i miłością bliźnich słynęli, składać także będą część pisma mego ${ }^{44}$.

Na zakończenie podał warunki prenumeraty na 1830 rok, czyli na tom drugi, na który miały się złożyć również cztery poszyty ukazujące się na początku każdego kwartału. Prenumeratę przyjmowano na wszystkich stacjach pocztowych w Królestwie Polskim oraz w księgarniach: w Warszawie u xx. pijarów, Zawadzkiego i Węckiego oraz Kermena, w Krakowie u Józefa Czecha i „w Wiedniu w księgarni Schrämbla przy ulicy Dorothergasse No I, III". Cena tomu (rocznika) na papierze zwyczajnym wynosiła 24 zł, a na piękniejszym 26 zł.

Prenumeratę zbierano już na tom pierwszy, bo 10 czerwca 1829 roku w notce zamieszczonej w prasie Ujazdowski prosił „osoby, które się raczyły po wojewódz-

43 „Gazeta Polska” 1829, nr 42, s. 185-186; nr 95, s. 282; nr 116, s. 498; o ukazaniu się trzeciego poszytu poinformował Ujazdowski 24 lipca („Gazeta Polska” 1829, nr 195, s. 848).

44 Idem, Prospekt na pismo czasowe „Pamiętnik sandomierski”, „Gazeta Polska” 1829, nr 304, s. 1316. 
twach zająć zbieraniem prenumeraty na niniejsze pismo, aby nadesłały listę imienną prenumeratorów do księgarni xx. pijarów lub na ręce wydawcy" do 20 czerwca, aby pełna ich lista mogła być umieszczona w czwartym poszycie ${ }^{45}$. Sprzedaż poszczególnych poszytów, jak również prenumerata, nastręczała Ujazdowskiemu kłopotów, o których informował publiczność. Na przykład w kwietniu 1830 roku zawiadamiał, że „Redakcja Pamiętnika Sandomierskiego oznajmia osobom życzącym to pismo nabyć, iż na papierze berlińskim zabrakło już egzemplarzy. Na zwyczajnym można jeszcze dostać po cenie oznaczonej w Warszawie w księgarniach, na prowincji po stacjach pocztowych"46.

„Pamiętnik” zaprenumerowało 61 osób i Biblioteka Zamoyskich. Wśród prenumeratorów byli przedstawiciele władz, duchowieństwa i obywatele województw kaliskiego, krakowskiego, sandomierskiego i podlaskiego. Najliczniejszą grupę stanowili przedstawiciele urzędników i profesorów warszawskich. W końcu pierwszego roku ukazywania się „Pamiętnika”, 1 grudnia 1829 roku, Ujazdowski przekazał drogą służbową pismo do cara z prośbą o wsparcie, dołączając do niego wydane już części kwartalnika. Minister Stanisław Grabowski siedem miesięcy później, 24 czerwca 1830 roku, przesłał je ministrowi sekretarzowi stanu z bardzo życzliwą opinią. Przyznano Ujazdowskiemu 390 zł, car zaś postanowił zaprenumerować „Pamiętnik” (,redakcja upoważniona jest przeto do umieszczenia imienia N[ajjaśniejszego] Pana na czele prenumeratorów") i kupić 15 egzemplarzy. Decyzję tę zapisano w piśmie z dnia 24 listopada 1830 roku, nie wiadomo jednak, czy doszła do redaktora, który jeszcze nie wrócił ze Śląska i prawdopodobnie nigdy nie dowiedział się o niej ${ }^{47}$. „Gazeta Polska” 30 sierpnia 1830 roku informowała, że w lutym tego roku KRWRiOP poleciła „Pamiętnik” ,szkołom wyższym”, czyli szkołom wojewódzkim ${ }^{48}$.

Przedmowe wydawcy Ujazdowski dołączył do czwartego poszytu (tom pierwszy) razem ze spisem treści tomu i listą prenumeratorów. Pisał ją, gdy wspomniana lista nie była jeszcze gotowa. Wyjaśnił w Przedmowie, że nazwał swe pismo „Pamiętnikiem Sandomierskim”, ponieważ „województwo sandomierskie będąc od wieków cząstką Polski ma do tego równe prawo jak Warszawa, Wilno, Lwów lub inne województwo", a także dla uczczenia sandomierzanina Kazimierza Malinowskiego żyjącego w XVII wieku, którego rękopis opublikował i tym samym przywrócił pamięci Polaków. Po latach historyk Andrzej Zieliński tak komentował zamysł ideowy nowego pisma: „tytuł i oczywiście zawartość akcentowały zwrot do partykularza, do dziewiczych terenów, które oczekiwały na historyka, badacza dawnej literatury czy etnografa" 49 .

45 „Gazeta Polska” 1829, nr 154, s. 670; „Gazeta Warszawska” 1829, nr 153, s. 1478.

46 „Kurier Polski” 1830, nr 85, s. 436; „Gazeta Polska” 1830, nr 100.

47 A. Patkowski, op. cit., s. 222.

48 „Gazeta Polska” 1830, nr 232.

49 A. Zieliński, Początki wieku. Przemiany kultury narodowej w latach 1807-1832, Łódź 1973, s. 31. 
„Pamiętnik” drukowała zasłużona Drukarnia XX. Pijarów. Z niewiadomych przyczyn od strony 399 tomu drugiego, czyli od 16 arkusza (trzeciego poszytu), druk kontynuował mało znany drukarz, Aleksander Rylle, działający wówczas w Warszawie ${ }^{50}$. Pierwsze trzy poszyty tomu pierwszego mają zaskakującą numerację stron - poszyt pierwszy kolejno: 24 strony nieliczbowane, 75 stron liczbowanych i 20 stron nieliczbowanych; poszyt drugi: 22 strony nieliczbowane i dalej numerowane od 23 do 112, a poszyt trzeci: numerowane strony od 239 do 334.

Między drugim a trzecim poszytem brakuje 7 stron — spis treści ten fakt potwierdza. Końcowe strony nieliczbowane w pierwszym poszycie i początkowe nieliczbowane w następnym obejmują przedruk XVI-wiecznej broszury Dionizego Catona pt. Cathonis disticha moralia Erasmo Rotherdamo latino castigatore, novissime Polono idiomate exornata. Katonowe wiersze... (Cracoviae 1582). Ponieważ przedruk tekstu opatrzono przedrukiem strony tytułowej, można domniemywać, że wydawca liczył się z możliwością wydania broszury w formie odbitki.

\section{PRACE NAUKOWE I EDYTORSKIE W „PAMIĘTNIKU SANDOMIERSKIM”}

Na początku każdego tomu „Pamiętnika” Ujazdowski umieszczał tekst religijny w języku polskim w staropolskim tłumaczeniu. Tom pierwszy otwiera Dziesięcioro przykazania drukowane gotykiem, które Ujazdowski wypisał z inkunabułu Wernera Rolewincka Fasciculus Temporum (Venetia 1480). W tomie drugim pierwszym tekstem jest przekład antyfony Salve Regina napisanej prawdopodobnie przez Hermanusa z Reichenau zwanego Contractusem (zm. 1054). Ze zbiorów Biblioteki Publicznej przy Uniwersytecie Warszawskim (wówczas posiadała ponad 116 tysięcy książek), w której był od stycznia 1828 roku dietariuszem, opublikował wspomnianą już broszurę Cathonis disticha moralia, Krzysztofa Chodkiewicza Blogosławiony Stanisław Kostka z Rostkowa (Kraków 1606), Senntentia albo zdanie JE ${ }^{o}$ M. księdza arcybiskupa gnieźnieńskiego Stanisława Karnkowskiego [...] o odjeździe Króla JE M. do Szweciey na seymie warszawskim (Poznań 1593), Powieść o rzeczy istey o założeniu na Łysey Gorze Braciey Zakonu Świętego Benedykta i też o tym iako drzewo świętego krzyża na gorę iest przyniesione (b.m.r.) ${ }^{51}$. Ujazdowski przedrukował te broszury ze względu na ich rzadkość. W pierwszych trzech przypadkach zaznaczył, że tekst udostępniła mu Biblioteka Publiczna przy Uniwersytecie Warszawskim. O posiadaniu czwartej broszurki przez tę Bibliotekę informował Wacław Aleksander Maciejowski. Nie-

${ }^{50}$ Informację o zmianie drukarni zamieszczono w „Pamiętniku Sandomierskim” 2, 1830, s. 436 .

51 „Pamiętnik Sandomierski” 1, 1829, s. nlb. 42; 2, 1830, s. 423-427, 457-488, 489-506; K. Estreicher, Bibliografia Polska, t. 14, s. 98, 182; t. 19, s. 122; t. 25, s. 183-184. W.A. Maciejewski, Piśmiennictwo polskie. T. 3, Dodatki, Warszawa 1852, s. 341-342. 
znane jest źródło przedrukowanego w „Pamiętniku” druczku Pieśń nowa o Gdańsku teraz znowu uczyniona, Roku Bożego 1577 (b.m.w.) ${ }^{52}$.

Korzystał też z innych bibliotek. List Leopolda C[esarza]N[ajjaśniejszego] do Jana III K[róla] $P[$ olskiego] pisany $r$. 1689, w którym donosi o dwóch zwycięstwach odpisał w bibliotece pijarskiej w Piotrkowie Trybunalskim ${ }^{53}$. W czasie podróży do Wiednia w sierpniu 1829 roku, przeglądając księgozbiór pojezuicki w Cieszynie, pod ostatnią okładką książki znalazł tekst polskiej pieśni żołnierskiej, wpisanej tam pod koniec XVI wieku, Piękne jest koło rycerskie. Jak pisał: „odkrycie tej pieśni naprowadziło mnie na myśl śledzenia onej dawności między ludem Szląskim, lecz czas był za krótki do zrobienia ściślejszego śledzenia, a następnie przypadek przy Prosteiowie ${ }^{54}$ przekonał mię, iż obcemu w obcym państwie niebezpieczno, choćby najniewinniejszych postrzeżeń naukowych czynić, musiałem więc na tym poprzestać, co znalazłem". W połowie października 1829 roku zamieścił w prasie warszawskiej prośbę do „miłośników rzeczy narodowych o pieśń żołnierską zaczynającą się od wyrazów Jedzie [Idzie] żotnierz borem lasem, przymierajac z głodu czasem".

Prosił też o nazwisko twórcy. Odzew był niemal natychmiastowy. Już po tygodniu pierwszy tekst pieśni zamieścił „Goniec Krakowski”, a nieco później dwa teksty ukazały się w „Gazecie Polskiej”. Ujazdowski dość szybko ustosunkował się do dziewięciu otrzymanych odpowiedzi i wyrażonych prawdopodobnie w nich opinii. Oburzyło go mianowicie to, że „wielu osobom [pieśń ta] zdawała się niegodną wiadomości publicznej”, dlatego „,jedynie, że przez lud wiejski jest śpiewana". Ostatecznie redaktor otrzymał kilkanaście wersji pieśni i na początku stycznia 1830 roku zawiadomił publiczność, że więcej tekstów nie potrzebuje. O otrzymanych wersjach napisał: „Nie godzi się jednak dowolnie różnicy wymyślać, dodawać, skracać lub faktów historycznych naciągać, jak to zrobił jeden. Chciał on tę pieśn tak uszykować i przyczepić do factum historycznego, jak jest owa znana pieśn Pod Puttuskiem pod miasteczkiem, stoi hetman z wojskiem polskim”. Do tego dołączył tekst odkryty w Cieszynie. W „Pamiętniku” znalazła się ta właśnie Pieśń rycerska (inc.: „Piękne jest koło Rycerskie”) i dwie wersje pieśni Jedzie żotnierz borem, lasem ${ }^{55}$. W 1830 roku jeszcze raz prosił Ujazdowski publiczność o nadesłanie „śpiewek” - tym razem napisanych przez Ostrowskiego,

52 „Pamiętnik Sandomierski” 2, 1830, s. 507-511.

53 Ibidem, s. 220-222.

54 Prostějov, czeskie miasto na południowy zachód od Ołomuńca; nic nie wiadomo o zdarzeniu, do którego Ujazdowski uczynił aluzję.

55 Pieśń starożytna rycerska..., s. 109-114; „Kurier Warszawski” 1829, nr 274, s. 1235; „Gazeta Polska” 1829, nr 274, s. 1193; „Goniec Krakowski, dziennik polityczny, historyczny i literacki” 1829, nr 126, s. 1021-1022; przedruk w: „Gazeta Polska” 1829, nr 286, s. 1242; „Gazeta Polska” 1829, nr 290, s. 1256; nr 296, s. 1282; T. U[jazdowski], Artykuł nadesłany, „Kurier Warszawski” 1829, nr 289, s. 1297-1298; [T.] U[jazdowskiI], Artykuł nadesłany, „Gazeta Polska” 1830, nr 2, s. 2 . 
proboszcza w Piotrkowie Trybunalskim - i wiadomości o ich autorze, ale nieznane są wyniki tego wezwania ${ }^{56}$.

Bardzo ciekawy przypis umieścił redaktor „Pamiętnika” w jego tomie pierwszym do drugiej części wypisu z akt siewierskich:

Akta, z których niniejsze wypisy czynię, poczynają się w mowie naszej na roku 1422 i następnie idą z małymi przerwami do XVII wieku. Zamierzyłem był sobie podług biegu lat umieszczać w niniejszym piśmie wyjątki, lecz nieprzewidziane trudności stanęły na przeszkodzie, a nade wszystko wypadało mieć oryginał pod ręką lub też uprosić osobę biegłą w czytaniu dawnych pism, by odpisywaniem się zajęła. - W obydwóch razach trudno zaradzić było - musiałem więc to odłożyć do następnego tomu Pamiętnika; tu zaś umieszczam to, co względny na mnie, a troskliwy o rzeczy Narodowe Prezes Komisji Województwa Krakowskiego [Kasper] Wielogłowski ${ }^{57}$ odpisać i nadesłać kazał z nadmienieniem tym: „Że gdyby Redakcja »Pamiętnika Sandomierskiego« więcej takowych wypisów potrzebowała lub ułamkowe wiadomości kraj interesujące mieć sobie z miejsca w W[ojewó]dztwie Krakowskim położonego życzyła, raczy Komisją W[ojewó]dztwa uwiadomić, o co wydawca już wspomnioną upraszał i spodziewa się skutku pomyślnego"58.

Więcej wypisów z akt siewierskich w „Pamiętniku” nie było. Prezes Wielogłowski był bardzo krytyczny wobec rektora kieleckiej szkoły Andrzeja Polejowskiego, natomiast poznawszy Ujazdowskiego, doceniał jego działalność pozaszkolną i starał się mu ją ułatwiać. Wysoki urzędnik podległy prezesowi, Franciszek Bogdański, kolekcjoner i „miłośnik starożytności”, przekazał Ujazdowskiemu list Walentego z Dębian Dębińskiego do generała miechowitów, który po wykorzystaniu przez redakcję został, zgodnie z życzeniem ofiarodawcy, oddany „dla zachowania” Bibliotece Publicznej przy Uniwersytecie Warszawskim ${ }^{59}$.

Nie wiadomo, kto Ujazdowskiemu przekazał dokument nobilitacji Andrzeja Bełzy, miejskiego rajcy Krakowa, z zastrzeżeniem, aby po jego wykorzystaniu przez redaktora został przekazany „dla zachowania” Towarzystwu Przyjaciół $\mathrm{Nauk}^{60}$.

Spośród współczesnych autorów dwa wiersze — Pieśń w czasie Sobótki śpiewana (Myśl z pieśni gminnej) i Madejowe toże (z powieści gminnej) — zamieścił w „Pamiętniku” Adam Podymowicz. Korektor samowolnie, mimo protestów auto-

56 „Gazeta Polska” 1830, nr 100.

57 Kasper Wielogłowski (1768-1846), prezes Komisji Województwa Krakowskiego w latach 1816-1832 i prezes senatu rządzącego Wolnego Miasta Krakowa w latach 1833-1846.

58 Wypis I. Z akt Siewierskich z księgi Inscriptionum inductarum zwanych i wypis II (tytuł według spisu treści): Wypisy w mowie polskiey z akt Siewierskich z lat 1481 i 1505, „Pamiętnik Sandomierski" 1, 1829, s. 39-40, 386-391, część pierwszą wydrukowano czcionką gotycką i w obu częściach zupełny brak interpunkcji; zob. przyp. na s. 389-390.

59 List Walentego z Dębian Dębickiego Kanclerza Koronnego do Generała Miechowitów Pisany r. 1566, „Pamiętnik Sandomierski” 2, 1830, s. 88-91. Dar F. Bogdańskiego został odnotowany przez „Kurier Warszawski” 1830, nr 21.

60 Uszlachcenie Andrzeja Betzy R[ajcy] M[iasta] Krakowa r. 1633, „Pamiętnik Sandomierski" 2, 1830, s. 74-82. Dokument otrzymało Towarzystwo przed 30 kwietnia 1830 roku — zob. J.U. Niemcewicz, Zagajenie posiedzenia publicznego Towarzystwa Królewskiego Warszawskiego Przyjaciót Nauk dnia 30 kwietnia 1830 r., „Gazeta Warszawska” 1830, nr 119. 
ra i redaktora, zmienił imiona chłopskich bohaterów ${ }^{61}$. Dawid Bergemann przesłał redaktorowi napisaną przez siebie Powieść o wyspie Siemko położonej na ieziorze Sleczyńskim, rzecz opartą na ludowej przypowieści z okolic Konina ${ }^{62}$.

Artykuł profesora astronomii Uniwersytetu Warszawskiego, Franciszka S. Armińskiego, Opis góry $S^{\text {to }}$ Krzyskiej z uwiadomieniem o czynnościach astronomicznych dotyczacych się pomiarów powierzchni górniczo-fabryczney, z polecenia Kommissyi Rzą. Przych. I Sk.[...] w letnich miesiacach r. 1828 i 1829 uskutecznionych jest w „Pamiętniku” zupełnym wyjątkiem. Informuje o pracach mających na celu dokładne udokumentowanie geodezyjne terenów podległych Komisji Rządowej Przychodów i Skarbu, którą kierował Franciszek Ksawery Drucki-Lubecki. W formie przypisu redaktor dołączył spis roślin znalezionych na tym terenie przez adiunkta Uniwersytetu Warszawskiego Wojciecha Jastrzębowskiego ${ }^{63}$.

Tomasz Ujazdowski jest prawdopodobnie autorem obszernego opracowania pt. Opis historyczny Miasta Kielc, w którym wykorzystał źródła drukowane i rękopiśmienne, a przy ich omawianiu zwrócił uwagę na konieczność krytycznego korzystania z nich. Stołeczność Kielc wymagała szerszej informacji, nie tylko historycznych, dotyczących miasta i województwa. Stąd w przypisie znalazło się przemówienie Alojzego Krauzego, który kierował górnictwem w Królestwie Polskim (w Zagłębiu Staropolskim), wygłoszone w 1816 roku z okazji ustanowienia Dyrekcji Górniczej ${ }^{64}$.

W tomie pierwszym „Pamiętnika” Ujazdowski zamieścił swój artykuł Kościól $w$ Seceminie, który jest przedrukiem z „Monitora Warszawskiego"65. Tam też znajdują się dwie relacje pisane w pierwszej osobie ze zwiedzania wsi na pograniczu mazowiecko-podlaskim: Wieś Budzieszyn albo Zbudeszyno w ziemi Drohickiej oraz Wiadomość o kościołach w Liwie, Pniewniku, w Wierzbnie w ziemi Liwskiej, Xięstwie Mazowieckiem ${ }^{66}$. Region ten, wydaje się, był bliski autorowi. Zwiedzał wymienione miejscowości dwukrotnie — w latach 1816 i 1819. Z tymi terenami związany jest też temat artykuliku Trzystoletnia sprawa. Pretekstem

61 „Pamiętnik Sandomierski” 2, 1830, s. 261-277; protest A. Podymowicza — „Gazeta Polska” 1830, nr 107, s. 2. Adam Podymowicz, mgr filozofii, zmarł 17 sierpnia 1830 roku w wieku 30 lat - „Gazeta Polska” 1830, nr 246, s. 1.

62 „Pamiętnik Sandomierski” 1, 1829, s. 23-29.

63 „Pamiętnik Sandomierski” 2, 1830, s. 427-436, tab. 2, tabl. skł. 1; spis roślin znalezionych przez W. Jastrzębowskiego, s. 429.

64 „Pamiętnik Sandomierski” 1, 1829, s. 55-97, mowa A. Krauzego - s. 92-95. W bibliografii zawartej w Dziełach wszystkich O. Kolberga (t. 76, Kieleckie. Suplement do tomów 18-19, oprac. E. Antyborzec, H. Pawlak, Poznań 2011) na s. 620 podano, że autorem tego artykułu jest F. Jabłoński.

65 Kościót w Seceminie, „Pamiętnik Sandomierski” 1, 1829, s. 46-50. T. U[jazdowski], O kościele w mieście Secyminie i Klasztorze Ś. Anny pod Przyrowem..., s. 41; przedruk w: „Rozmaitości Literackie z roku 1827" 4, Warszawa 1828, s. 1-2.

66 „Pamiętnik Sandomierski” 1, 1829, s. 364-368, 371-378. 
było wznowienie procesu sądowego między dwoma wsiami szlacheckimi: Lipki i Maliszowa. Sądy od 1494 roku próbowały spór zakończyć, ale bez skutku ${ }^{67}$. Wieś Danków w województwie Kaliskiem, powiecie obwodzie Wieluńskim ${ }^{68}$ najprawdopodobniej również jest relacją z pobytu Ujazdowskiego w tej miejscowości w czasie jednej z jego podróży na Śląsk.

Wynikiem pobytu Ujazdowskiego w Krakowie w czasie studiów i zwiedzenia tamtejszego klasztoru franciszkanów było zainteresowanie życiem Franciszka Jabłońskiego. W Krakowie znalazł niewiele wiadomości na jego temat, dlatego, jak sam pisze, „chcąc jednak uniknąć czczej panegeryi, przedsięwziąłem mówić o tym, co mogłem trafić w klasztorach franciszkańskich w Warszawie, Krakowie, Lwowie, Poznaniu, Lelowie, Korczynie; bo w tych Jabłoński mieszkał". Ze Śląska sprowadził rękopis największego dzieła franciszkanina i dołączył go do napisanego przez siebie życiorysu ${ }^{69}$. Do zajęcia się twórczością innego zakonnika z przełomu XVI i XVII wieku, dominikanina Gabriela Leopolity, przekonały go potrzeby naukowe:

Bibliografia jak w innych krajach tak i w Polsce nie sięga swym początkiem odległych wieków starożytności; zatem jak za granicą tak i u nas nie doszła jeszcze stopnia doskonałości. Nic przeto dziwnego, że jak w pisarzach obcych, tak i w naszych wiele sprzeczności napotykamy. Obowiązkiem niejako jest osób mających upodobanie w tej nauce takowe wykazywać. Powodowany tą myślą, przedsięwziąłem zebrać różne zdania o dziełach ks. Gabriela Leopolity i drukarza tychże Janie Szelidze ${ }^{70}$.

Ciekawy jest obszerny przypis wyjaśniający pochodzenie słowa „rokosz”. Czy wszystkie książki Leopolity miał Ujazdowski w ręce — trzeba wątpić, bo w dwóch przypadkach powołał się na bibliografie Adama Tomasza Chłędowskiego i Jana Chyliczkowskiego, ale w podsumowaniu napisał: „We wszystkich dziełach Leopolity druk gocki piękny, holesztychów [tj. drzeworytów], z tych niektóre piękne, mnóstwo szczególnie w Oratorium pałaczu duchownego, polszczyzna czysta, erudycja niepospolita; łagodność ewangeliczna w wyrażeniach ku różnowiercom, a częściej nawet unikanie drażliwości cechują tego kaznodzieję"71.

W czasie podróży na Śląsk poznał mowę ludu śląskiego i w krótkim artykule przy toczył dwa dokumenty (zaświadczenie wójta i list ucznia do ojca), które poprzedził wstępem: „Mowa Polska między ludem Szląskim utrzymuje się wprawdzie, lecz miejscami, szczególniej w klasie ludu przemysłowej, tak jest z niem-

67 Ibidem, s. 416-417.

68 Ibidem, s. 97-107.

69 T. Ujazdowski, Życie i pisma Franciszka Jabłońskiego..., s. 239-249; F. Jabłoński, Herby rycerstwa Polskiego, „Pamiętnik Sandomierski” 1, 1829, s. 249-353. Ogółem 115 stron — 1⁄4 objętości pierwszego tomu.

70 T. Ujazdowski, O dziełach X. Gabryela Lwowczyka Zakonu Kaznodzieyskiego, „Pamiętnik Sandomierski" 1, 1829, s. 354-363.

71 Ibidem, s. 357, 358-360. 
czyzną pomieszana, że Niemiec i Polak rozmawiających Szlązaków rozumieć nie mogą nie posiadając obydwóch języków dostatecznie"72.

Pamiętniki Kazimierza Malinowskiego Sandomierzanina i wiadomości o jego życiu Ujazdowski miał na myśli, pisząc w Przedmowie wydawcy, że wydarł go niepamięci. Rękopis Pamiętników - właściwy ich tytuł: Compendium Juris Polonici usibus Polonorum applicatum — nabył na Śląsku. Na podstawie zapisów dotyczących osobiście Malinowskiego i jego rodziny Ujazdowski napisał życiorys sandomierzanina jako gospodarza i prawnika. Szczególnie dużo miejsca poświęcił sprawom gospodarczym - co i gdzie zasiano, ile zebrano i sprzedano w roku gospodarczym 1682 i 1683 - i tak uzasadnił ich umieszczenie w „Pamiętniku”: „Wymieniany wysiew, zbiór, sprzedaż, wydatki gospodarcze, mogą wprawdzie nudzić mało-myślącego, lecz jak są ważne dla historii a nawet samego gospodarstwa?” Z tego rękopisu redaktor „Pamiętnika” opublikował 10 dokumentów, w tym mowę króla Jana III Sobieskiego w senacie po zerwaniu sejmu w 1681 roku oraz listy poparcia w staraniach pana Kazimierza o rękę Elżbiety vel Ewy Przyłęckiej ${ }^{73}$. Mowę króla w spisie treści tomu opatrzył uwagą: „Mowa ta znajduje się w tomie II Listów [Andrzeja Chryzostoma] Załuskiego zupełnie po łacinie: początek zgadza się, lecz ta jest obszerniejszą i więcej szczegółów zawiera”.

Z posiadanych książek redaktor „Pamiętnika” publikował fragmenty. Takim był List z Rzymu do przyiaciela oznaymuiący ceremonie po śmierci Oyca Świętego i przy obraniu nowego (r. 1740 pisany przez Polaka) opisujący wydarzenia roku 1740 w Rzymie po śmierci papieża Klemensa XII. Został wyjęty z książki pijara Samuela Wysockiego Traktatus de Formandis Epistolis Iuxta Norman Veterum Recentiorum; scriptorum oratori Polono (Cracoviae 1743, s. 60-75). Natomiast Obrazy w Ossiach albo Ossie w Karyntyi, wyjęte z dzieła Piotra Pruszcza Forteca monarchów y całego Krolestwa Polskiego z 1737 roku, Ujazdowski opatrzył swoim komentarzem. Powtórzył zdanie polskich historyków Adama Naruszewicza, Tadeusza Czackiego i Joachima Lelewela, że malowidła w Ossie przedstawiające najważniejsze sceny z życia polskiego króla Bolesława Śmiałego i związane z nimi legendy nie są prawdziwe ${ }^{74}$. Nie wiadomo, co było przyczyną, że Wiazd wspaniały Jerzego z Tenczyna Ossolińskiego, posła Króla Jmci Władysława IV do Rzymu dnia 27 Listopada r. 1633 ukazał się nie tylko w „Pamiętniku”, ale także w osobnej odbitce ${ }^{75}$.

72 T. Ujazdowski, Mowa polska w Szląsku proza, „Pamiętnik Sandomierski” 1, 1829, s. 369371.

73 „Pamiętnik Sandomierski” 1, 1829, s. 2-39. Uzasadnienie dotyczące wiadomości gospodarczych redaktor zamieścił w spisie treści (Przedmioty umieszczone w tomie I Pamiętnika Sandomierskiego i nad temi uwagi). Wydanie mowy króla Jana III (s. 16-18) Ujazdowski zapowiedział w artykule Wspomnienie Narodowe, „Gazeta Polska” 1828, nr 307, s. 1225, w spisie treści tomu.

74 „Pamiętnik Sandomierski” 1, 1829, s. 108-110.

75 „Pamiętnik Sandomierski” 2, 1830, s. 399-405. 
$\mathrm{Z}$ rękopisu nieznanego autora $\mathrm{w}$ trzech bardzo obszernych odcinkach opublikował Ujazdowski Historyę królów szwedzkich od Eryka VI aż do Zygmunta Króla Polskiego i Szwedzkiego, czyli od r. 906 do 1632. Wcześniej z tegoż rękopisu, z części poświęconej historii Francji, zamieścił w „Pamiętniku” list papieża Benedykta XI potępiającego Wilhelma Nogareta, bliskiego współpracownika króla francuskiego Filipa Pięknego w początkach XIV wieku ${ }^{76}$. W Historyi królów szwedzkich we fragmencie informującym o oficjalnym uznaniu wyznania ewangelicko-augsburskiego za panujące w Szwecji przez króla Gustawa I Wazę redaktor dodał zdanie: „Co po tym nastąpiło, łatwo się doczy tać w książeczce, której tytuł Historyja Rewolucyi Szwedzkiej”. Do tego zdania dał obszerny przypis o bardzo poczytnej w Polsce anonimowo wydanej książce Auberta René Vertota Historya Rewolucyi Krolestwa Szwedzkiego y Duńskiego po polsku wyłożona przez Jana Potulickiego (prawdopodobnie: Warszawa 1701). Miała ona do 1756 roku trzy polskie wydania i dwa w przeróbce wierszowanej. O rzadkości pierwszego wydania zapewniał redaktor: „Dlatego powiedzieliśmy obszerniej o tym dziełku, bo nie tak go łatwo zoczyć: biblioteki krakowska, warszawska ${ }^{77}$, zachwalana z osobliwości Chyliczkowskiego nie mają onego; myśmy go przypadkowo w Wrocławiu nabyli”. Dalej wyjaśniał przyczyny jego ważności: „To dzieło wydane w mowie Polskiej z okoliczności politycznych, miało służyć za przykład i przestrogę narodowi naszemu, szybkim krokiem do upadku dążącemu, pogrążonemu w bezrządzie, swawoli możniejszych, nieoświeceniu duchowieństwa itd. Chociaż wprawdzie pisarz nie dopiął swego zamiaru, nie oświecił ciemnoty powszechnej, jednak wielu przeraził, nawrócił na drogę rozsądku, do jedności zachęcił i niebezpieczeństwo śmiało wskazał". Warto powyższy cytat zestawić z komentarzem dotyczącym przejścia Szwedów na luteranizm zapisanym w omawianym rękopisie: „Tu tylko zważyć potrzeba, jak wielkie jest królestw szczęście, gdy na jego urzędy osoby bywają wysadzone serca nieulęknionego, rozumu w radach niezbitego, które lubo uznają się być obowiązanymi łaskom królewskim, bardziej jednak ojczyźnie. Jak zaś przeciwnie szkodliwa rzecz i zguby pewna, gdy senat bez rady, rycerstwo bez odwagi, duchowieństwo bez nauk i tylko dworzkim [!] poszeptom się wyznaje, nie prawom ojczystym"78.

Relacja z rękopisu kończy się informacją, że 14 sierpnia 1594 roku król Zygmunt III wrócił do Gdańska po rocznym pobycie w Szwecji, gdzie objął rządy i został koronowany na króla tego kraju. Dopełnieniem są Przyczyny od Karola

76 „Pamiętnik Sandomierski” 1, 1829, s. 52-54; „Pamiętnik Sandomierski” 2, 1830, s. 4-73, 115-158, 279-307. T. Ujazdowski uważał, że rękopis powstał w I połowie XVIII wieku.

77 Biblioteka Uniwersytetu Jagiellońskiego w Krakowie i Biblioteka Publiczna przy Uniwersytecie Warszawskim.

78 „Pamiętnik Sandomierski” 2, 1830, s. 50-51. 
Xcia Sudermanii ${ }^{79}$ podane i do różnych Państw porozsyłane, osobliwie do Polski, dla których on nie dopuszczat, żeby Zygmunt krol Polski, po śmierci oyca swojego Jana krola Szwedzkiego nie mogt bydź krolem Szwedzkim, z odpowiedziami na $n i e^{80}$. Dokument pochodził z biblioteki XVIII-wiecznego kasztelana łęczyckiego Tadeusza Lipskiego ${ }^{81}$. W osiemnastu punktach Karol dowodził, że Zygmunt nie może być królem Szwecji, i w tyluż odpowiedziach podano argumenty, że mógł i powinien nim być. Problematykę stosunków polsko-szwedzkich uzupełniają: List od Nayiaśnieyszey Królowey Szwecyi do Stanów Królestwa Polskiego z 1572 roku i wspomniana wyżej Sententia albo zdanie JE ${ }^{o}$ M. Księdza Arcybiskupa Gnieźnieńskiego Stanisława Karnkowskiego wraz z Informatia w teyże sprawie na seymik od JE Mći podana oraz Pogrzeb Katarzyny Jagiellonki, Nayiaś. Zygmunta I Króla Pols. I Bony Sforcyi Król. Pol. córki, Królowej Szwedzkiey a matki Zygmunta III Króla Polskiego i Szwedzkiego, w Upsala d. 15 Lutego i następnych $1584 \mathrm{roku}^{82}$. Stosunkom polsko-szwedzkim Ujazdowski poświęcił 246 stron, czyli znacznie ponad $1 / 3$ objętości tomu drugiego.

Materiały dotyczące sprawy małżeństwa króla Zygmunta Augusta z Barbarą Radziwiłłówną rozpatrywanej na sejmie piotrkowskim w 1548 roku znalazły się w tomie drugim — od powitania króla przez posłów i jego odpowiedzi, przez czynności sejmu i pożegnanie króla przez posłów, po Pisemko na Zygmunta Augusta powtorne matżeństwo rozrzucone w Piotrkowie R.P. 1548. Do spraw tyczących się tego króla należą też: jego mowa do posłów na zakończenie sejmu lubelskiego 1568 roku oraz dwa programy uroczystego przewiezienia jego zwłok z Drohiczyna do Krakowa i pogrzebu na Wawelu ${ }^{83}$. Po śmierci Zygmunta Augusta zainteresowanie Mołdawii i Turcji elekcją nowego króla polskiego było duże. Turcja popierała kandydata francuskiego i zapewniała, że będzie starać się, aby w czasie bezkrólewia nie zakłócali spokoju Tatarzy krymscy ani Mołdawia. Pięć listów napisanych między 20 lutego a 23 kwietnia 1573 roku w tej sprawie — od wojewody mołdawskiego, Turcji i Stanów Koronnych — zamieścił Ujazdowski w „Pamiętniku” bez podania źródła ${ }^{84}$.

${ }^{79}$ Karol IX Sudermański (1550-1611), stryj Zygmunta III, który w 1594 roku mianował go regentem w Szwecji, w 1598 roku przeprowadził detronizację króla i w 1604 roku został jego następcą.

80 „Pamiętnik Sandomierski” 2, 1830, s. 308-366.

81 Tadeusz Lipski (1725-1796), kasztelan łęczycki, komediopisarz, aktywny działacz i pisarz polityczny, zbieracz literatury politycznej i innych materiałów historycznych.

82 „Pamiętnik Sandomierski” 2, 1830, s. 158-170, 459-488, 513-516. Katarzyna Jagiellonka (1526-1583), córka Zygmunta I Starego i Bony, wraz z mężem, królem szwedzkim Janem III Wazą (1537-1592), byli więzieni w latach 1563-1568 przez Eryka XIV Wazę. W Pogrzebie Katarzyny Jagiellonki Ujazdowski przywołał Monumenta Ullerakerensia cum Upsalia nova illustrata... Johana Peringskiölda, Stockholm 1719, gdzie osobie królowej poświęcono s. 68-74.

83 „Pamiętnik Sandomierski” 2, 1830, s. 83-88, 171-196, 381-382, 441-455.

84 Ibidem, s. 516-523. 
Niżej wymienione dokumenty wyczerpują materiały historyczne w „Pamiętniku”: Przywilej Xięcia Cieszyńskiego Przemysława z roku 1374, List Królowej Bony do Bagieńskiego r. 1542 pisany (właściwe dwa listy), Rzecz pana S. Podlodowskiego Liupy ku Królowi JMci Zygmuntowi Pierwszemu y do Panow Rad koronnych imieniem wszystkich Postow Ziemskich na Seymie w Piotrkowie Ao 1547, Stefan Batory zakazuie prześladować różnowierców w Litwie. List pisany [do Jana Abramowicza] z obozu pod Pskowem r. 1581 oraz Copia listu K. I. M. Władystawa do P. Podkanclerzego Koronne[go] [w sprawie] Królewicza JE Mczi Cazimirza, że do Zakonu OO. J[e]zui[tów] wstępuie [Warszawa, 9 listopada $1647 \mathrm{roku}$ ]. W przypisie do wspomnianego wyżej artykułu o Franciszku Jabłońskim podano pięć listów Jana Kazimierza do słynącego z pobożności włoskiego franciszkanina Józefa z Kopertynu, z prośbą o modlitwę w jego intencji. Pierwszy list przyszły król podpisał: „Jan Kazimierz jezuita nowicjusz”. Listy te Ujazdowski przejął z książki Roberta Nutiego Żywot stugi Bożego W. O. Józefa z Kopertynu, Kapłana zakonu S. Franciszka... (Kraków 1688) w przekładzie Franciszka Jabłońskiego ${ }^{85}$.

Należy dodać, że Ujazdowski, dysponując dokumentami podpisanymi przez królów i inne znakomite osoby, skopiował ich podpisy, a ich facsimile zamieścił w „Pamiętniku” na specjalnej tablicy dopełnionej komentarzem ${ }^{86}$.

W spisie treści tomu pierwszego przy wielu pozycjach dodawał komentarze bibliograficzne, co świadczy, że śledził nabytki różnych bibliotek. Tak np. przy Cathonis disticha moralia napisał: „Biblioteki Ossolińskich we Lwowie, Puławska posiadają go; nie mniej w zbiorze Jana Hrabi Tarnowskiego znajduje się; do zbioru hrabi Tytusa Działyńskiego egzemplarz w roku z[eszłym] przybył. To powodowało wydawcę do przedrukowania go, bez względu, że się może niejednemu czytelnikowi mogło tłumaczenie nie podobać".

Artykuł Baba Chęcińska został napisany przez bliżej nieznanego Szamotę jaki był udział Tomasza Ujazdowskiego przy jego powstawaniu, trudno ustalić, albowiem w sprawozdaniu z publicznego posiedzenia Towarzystwa Przyjaciół Nauk z dnia 15 grudnia 1828 roku o odkryciu w Chęcinach rzeźb Baby i Niemca napisano, że należy się wdzięczność „za przyłożenie się do odkrycia tego, równie jak gorliwemu nader o starożytności ojczyste jmci panu Ujazdowskiemu i Szamocie za napisanie o pomnikach tych uczonej i pracowite rozprawy". W sprawozdaniu z następnego posiedzenia (30 kwietnia 1829 roku) informowano: „Nad pismem Szamoty o tych posągach przez Tomasza Ujazdowskiego podanym czytał uwagi Lelewel. Znajduje tę wiadomość na miejscu zebraną, ciekawą i jeśli kto pisać

85 „Pamiętnik Sandomierski” 1, 1829, s. 244-248, 379-385, 414-415; „Pamiętnik Sandomierski" 2, 1830, s. 197-206, 553-557.

${ }^{86}$ Naśladownictwo podpisów wielkich lub wsławionych ludzi, Polakow i niektórych obcych należacych przecież do dziejów naszego narodu, „Pamiętnik Sandomierski” 2, 1830, s. 235-237, tabl. 


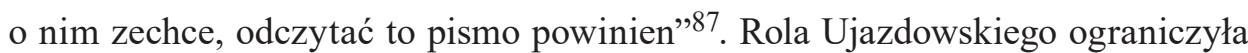
się tylko do zamówienia opisu rzeźb u Szamoty w Chęcinach i przekazania go Towarzystwu. W „Pamiętniku” zamieścił tekst Szamoty, który dopełnił swymi uwagami o charakterze komentarza. Prawdopodobnie opis został zamówiony za pośrednictwem Ferdynanda Chotomskiego z Kielc, który w Chęcinach wykonał rysunki trzech rzeźb, w tym Baby, i przekazał je Ujazdowskiemu ${ }^{88}$. Szamota najprawdopodobniej jest też autorem krótkiego artykułu o Babie pisanego „Z Chęcin dnia 1 września 1828 r." ${ }^{\prime 29}$ Autor artykułu Baba Chęcińska zastanawiał się nad pochodzeniem posągu w kontekście etnograficznym i historycznym i doszedł do wniosku, że przedstawia on dawną boginię, ale też wiedział o miejscowym ustnym przekazie, że tamtejsi kamieniarze dla zabawy wyrzeźbili Babę. Tę ostatnią wersję jej pochodzenia przyjął Franciszek Maksymilian Sobieszczański i dość żartobliwie potraktował artykuł Szamoty i Ujazdowskiego w „Pamiętniku” oraz zainteresowanie Towarzystwa Przyjaciół Nauk rzeźbą. W 1827 roku Łukasz Gołębiowski był skłonny poprzeć wersję „Pamiętnika”: „W Chęcinach są ułamki dwóch starożytnych posągów, lud prosty nazywa je Dziadem i Babą i uznaje w nich zabytki bałwochwalstwa naszego, co jest podobnym do prawdy"90.

T. Ujazdowski opublikował znaczną liczbę tekstów poetyckich (ponad 30) z sylwy XVII-wiecznego dworzanina Radziwiłłów, Stanisława Różyckiego (15961674), pt. Penu synopticum historii-grammato-politicum ${ }^{91}$. Prawdopodobnie Ujazdowski był pierwszym wydawcą, który przypomniał twórczość Olbrychta Karmanowskiego. Uczynił to bardzo niestarannie, obok utworów tego autora dał bowiem pod jego nazwiskiem dzieła innych poetów, m.in. Jana Kochanowskiego, Hieronima Morsztyna, Jana z Kilan. XIX-wieczni wydawcy utworów Karmanowskiego

87 Schamota [Szamota], Baba i Dziad w Chęcinach, rękopis podpisany przez autora 6 sierpnia 1828 roku w Chęcinach, AGAD, TPN, 28a, s. 173-183; J. Lelewel otrzymał rękopis Szamoty 16 października i omawiał go na posiedzeniu Działu Nauk Towarzystwa jako pracę Ujazdowskiego, ibidem, s. 186-187. [Szamota], Baba chęcińska, z uzupełnieniami T. Ujazdowskiego, „Pamiętnik Sandomierski" 2, 1830, s. 92-104, po s. 92 rycina przedstawiająca Babę; J.U. Niemcewicz, Zagajenie Sesssyi Publicznej Towarzystwa Królewskiego Przyjaciół Nauk w dniu 15 grudnia 1828, „Roczniki Królewskiego Towarzystwa Przyjaciół Nauk” 21, 1830, s. 123-124; idem, Zagajenie posiedzenia publicznego Towarzystwa Przyjaciół Nauk dnia 30 kwietnia 1829, „Roczniki Królewskiego Towarzystwa Przyjaciół Nauk” 21, 1830, s. 217.

${ }^{88}$ F. Chotomski do T. Ujazdowskiego, 11 maja 1828 roku, AGAD, TPN, 28a, s. 171-172, 184. Ferdynand Chotomski (1797-1880), oficer, przyrodnik, literat, był w latach 1824-1830 kuratorem szkół województwa krakowskiego.

89 „Gazeta Polska” 1828, nr 275 (9 października), s. 1097.

90 F.M. Sobieszczański, Wycieczka archeologiczna w niektóre strony guberni radomskiej odbyta w miesiącu wrześniu 1851 roku, Warszawa 1852, s. 203-204; Ł. Gołębiowski, Opisanie historyczne i statystyczne województwa Krakowskiego, [w:] idem, K. Puchała, Opisy historyczne województwa krakowskiego i sandomierskiego z lat 1823 i 1827, wyd. S. Adamczyk, Kielce 2003, s. 19.

91 Obecnie: Biblioteka Narodowa w Warszawie, sygn. BOZ 1162. 
mieli kłopoty z poprawnym ustaleniem autorstwa. Radosław Grześkowiak, ostatni wydawca wierszy tego poety, wyjaśnił postępowanie redaktora „Pamiętnika”:

Ujazdowski korzystał z [tzw.] przekazu P, w którym spośród licznych wierszy różnych autorów (m.in. Kochanowskiego, Klonowicza, Jana z Kilan, Szymonowica, Hieronima Morsztyna, Naborowskiego) autorsko oznaczono jedynie utwory Karmanowskiego. Nie znajdując innych atrybucji, wydawca bezkrytycznie rozciągnął jego autorstwo na całą skopiowaną tam kolekcję wierszy. Założenie takie pozwoliło mu w przedruku nie tylko dowolnie wybierać wiersze z manuskryptu, ale też łączyć utwory, których zapis oddalony był zarówno od dzieł sygnowanych nazwiskiem Karmanowskiego, jak i od siebie nawzajem ${ }^{92}$.

Jako wiersze Różyckiego zamieścił Ujazdowski w „Pamiętniku” cztery wiersze w języku niemieckim i jeden polski o zdradzie księcia Lobkowicza, czeskiego arystokraty, wysokiego dygnitarza austriackiego ${ }^{93}$. Z tego też rękopisu w „Pamiętniku" został przedrukowany Wiazd wspaniały Jerzego z Tenczyna Ossolińskiego posła króla Władysława IV do Rzymu dnia 27 listopada r. $1633^{94}$.

Mimo tych potknięć edytorskich zasługi T. Ujazdowskiego dla polskiej kultury były niepodważalne. Swoimi edycjami w „Pamiętniku Sandomierskim” ocalił bowiem dla potomności unikatowe zabytki dawnej literatury polskiej, skądinąd nieznane i niezachowane w oryginalnych wersjach rękopiśmiennych do naszych czasów. Do takich zabytków należały m.in. pieśń O Dymitrze i zbiorowe Elogium Wielkiego Księstwa Litewskiego z czasów panowania Zygmunta III, które znane są obecnie jedynie z jego edycji ${ }^{95}$.

Ujazdowski starał się „Pamiętnik Sandomierski” uczynić bardziej atrakcyjnym przez wykorzystanie ozdobnych elementów drukarskich, winiet umieszczanych nad tytułami artykułów i na okładkach wydawniczych obu tomów. Wykorzystując różne techniki (drzeworyt, miedzioryt, akwatintę i akwafortę), ozdabiał niektóre artykuły, np. w Historii królów Szwedzkich nad poszczególnymi życiorysami królów umieścił medaliony z ich portretami. Medalion z podobizną Sebastiana Klonowicza na doklejonej karcie (t. 2, po s. 552) poprzedza wiersz tego poety. O rycinie dodanej do artykułu Baba Chęcińska wspomniano wyżej. W tomie pierwszym przed kartą tytułową i na końcu doklejono dwie ryciny: Traktat z Moskwą r. 1634 i Traktat ze Szwecya 1620 r. Ciekawa jest trzy razy powtórzona

92 O. Karmanowski, Wiersze i listy, wyd. R. Grześkowiak, Warszawa 2010, s. 108.

93 „Pamiętnik Sandomierski” 2, 1830, s. 538-549, na s. 538 przyp.: „Poezje te są Różyckiego, polaka [!], o którym później damy obszerniejszą wiadomość" (takiej informacji jednak nie dano). Franciszek Siarczyński rok wcześniej przypomniał twórczość innego Lobkovica: Przekłady polskie wierszów łacińskich Bolesława Lobkowicza napisanych w wieku XV na pochwałe cieplic Karlsbadu, „Czasopism Naukowy Księgozbioru Publicznego Imienia Ossolińskich” 2, 1829, nr 3, s. $3-13$.

94 „Pamiętnik Sandomierski” 2, 1830, s. 399-405, odb. Warszawa 1830.

95 Zasługi Ujazdowskiego na tym polu wysoko ocenił J. Nowak-Dłużewski, Okolicznościowa poezja polityczna w Polsce. Zygmunt III, Warszawa 1971, s. 204-205, 369. Wspomniane utwory opublikowane zostały w „Pamiętniku Sandomierskim” 2, 1830, s. 410-414 i 557-563. 
winieta przedstawiająca orła w locie, a nad nim napis: ELEMENTUM MEUM LIBERTAS (t. 2, s. 1, 115, 279).

Ujazdowski, przystępując do wydawania staropolskich tekstów, nie ustalił, kto miał być odbiorą „Pamiętnika” — historyk literatury Andrzej Zieliński sądził, że wydawca liczył „na pokrewnego sobie czytelnika-zbieracza” i „starożytnika”. W przypisach lub uwagach wstępnych Ujazdowski zapewniał czytelników, że stare XV-, XVI- i XVII-wieczne teksty opublikował w oryginalnej pisowni, co już wówczas musiało budzić pewne wątpliwości. Przeciętnemu czytelnikowi musiało to bardzo utrudniać lekturę. Julian Ursyn Niemcewicz, wydawca największego wówczas zbioru tekstów staropolskich, zastosował w druku pisownię z lat 20. XIX wieku. Podobnie postąpił znany regionalista Wincenty Hipolit Gawarecki, wydając Przywileje, nadania i swobody przez polskich xiążą mazowieckich $i$ biskupów płockich udzielone miastom województwa płockiego (Warszawa 1828). Ambroży Grabowski, wydając w 1840 roku swoje Starożytności polskie, czyli pisma i pamiętniki do dziejów dawnej Polski, starał się zachować dawną pisownię. Joachim Lelewel, przygotowując wydanie Zbioru praw litewskich od roku 1389 do roku 1529 (Poznań 1841), pisał do wydawcy: „Niech nikogo niestateczność ortografii nie obraża, poprawiać jej nie śmiałem i nie godziło się ani w ruskim, ani w polskim tekście. Nie tworzymy nowej ortografii, ale starą zachowujemy"96. Niemcewicz nie informował, skąd pochodziły teksty, które ogłaszał. Ujazdowski w niewielu przypadkach podał źródła. Gawarecki zapewniał, że starał się o dokumenty oryginalne lub poświadczone w metryce koronnej ${ }^{97}$. Może też te uchybienia były przyczyną skromnej liczby prenumeratorów „Pamiętnika”.

„Pamiętnik Sandomierski” zdobył należne uznanie w Polsce i za granicą. W 1830 roku w „Revue Encyclopédique” w omówieniu 37 czasopism polskich napisano o nim: „Jest to najszacowniejsze z pism w tym kraju wychodzących”98. Z kolei w mowie na posiedzeniu centralnym Towarzystwa Przyjaciół Nauk 7 listopada 1830 roku jego prezes, Julian Ursyn Niemcewicz, powiedział: „pisma periodyczne nasze roznosząc wszędzie wiadomości nowych dzieł odkryć czy to geograficznych, czy umiejętności i sztuk pięknych »Pamiętnik Naukowy«, »Pamiętnik Sandomierski« całkiem starożytnościom polskim poświęcony i tyle innych, które zbyt było długo wyliczać. Są one jak zbawienne strumienie rozlewają-

96 A. Grabowski, Starożytności polskie czyli pisma i pamiętniki do dziejów dawnej Polski, listy królów i znakomitych mężów, przypowieści, przystowia itp., z rękopisów zebrał i przydał Żywoty uczonych Polaków..., t. 1-2, Kraków 1840.

97 Zbiór pamiętników historycznych o dawney Polszcze z rękopismów, tudzież dzieł w różnych językach w Polszcze wydanych oraz z listami oryginalnemi Królów znakomitych ludzi w kraiu naszym przez J.U. Niemcewicza, t. 1-5, Warszawa 1822-1830; J. Lelewel do Tytusa Działyńskiego, 7 października 1830 roku, Korespondencya Joachima Lelewela z Tytusem Działyńskim, wyd. Z. Celichowski, Poznań 1864, s. 54.

98 „Gazeta Polska” 1830, nr 291. 
ce się po kraju i użyźniające umysłowe zdolności mieszkańców i rozwijające gust nauk, skłonności odwracające od tylu innych szkodliwych"99.

\section{REDAGOWANIE, ,TANDECIARZA”}

Gdy na początku grudnia 1830 roku Ujazdowski powrócił do Warszawy, nie było już warunków do kontynuowania „Pamiętnika Sandomierskiego”. Postanowił wydawać nowe pismo, tym razem satyryczne, zaangażowane politycznie po stronie Towarzystwa Patriotycznego, szczególnie jego radykalnego skrzydła. Numer pierwszy pisma ukazał się w pierwszych dniach lutego (na stronie tytułowej podano datę 2 stycznia) 1831 roku wraz z kartą tytułową dla całego tomiku. Oto treść strony tytułowej: „Tandeciarz. Pismo bardzo pożyteczne dla rycerzów, prawników, gospodarzy, rzemieślników, księży, mnichów, mniszek i t. d. wydawane przez Bogdana Walkę; w Parzymiechach krotłami Kupisza; nakładem Goliata". Przyjęty dla nowego czasopisma tytuł oznacza handlarza starzyzną, tandetą. Sam Ujazdowski ukrywał się natomiast pod dwoma pseudonimami: jako wydawca był Bogdanem Walką, a jako nakładca - Goliatem. Od ostatnich dni kwietnia wydawcą i redaktorem był ks. Bogdan Walka. Już po zawieszeniu wydawania „Tandeciarza” ten pseudonim pojawił się w ostatnich dniach sierpnia w dwóch anonsach w „Gazecie Polskiej”. W pierwszym z nich (nr 231 z dnia 28 sierpnia) pisano: „Ksiądz Bogdan Walka, Misjonarz, redaktor »Tandeciarza« poległ śmiercią walecznych pod Ostrołęką dnia 26 maja r. b., mówią jednak, iż jego sukcesorowie pismo nadal wydawać będą", a w drugim (nr 234 z dnia 31 sierpnia): „Księża Misjonarze mają odprawić w przyszły piątek żałobne nabożeństwo za duszę ś. p. Księdza Bogdana Walki, członka swego Zgromadzenia, redaktora »Tandeciarza«, który, jak już donieśliśmy, poległ z orężem w ręku pod Ostrołęką. Przyjaciele nieboszczyka zapewne zgromadzą się licznie na ten obrzęd żałobny". Do tego pseudonimu powrócił Ujazdowski w okresie swojej działalności konspiracyjnej w 1836 roku. List do Jana Nepomucena Janowskiego z dnia 9 kwietnia 1836 roku podpisał: „Bogdan”, a na odwrotnej stronie dopisano: „Pod adresem Walki możesz i do mnie pisać"100.

Miejscem wydania „Tandeciarza” uczynił Ujazdowski wieś Parzymiechy k. Częstochowy, a nieznany drukarz tłoczyć miał pismo czcionkami Kupisza, prawdopodobnie Łukasza (ok. 1600-1655), krakowskiego księgarza i drukarza. „Tandeciarza” drukował wspomniany już Aleksander Rylle w Warszawie. Nazewnictwo strony tytułowej nawiązuje, jak zauważyła Barbara Wolska, do tradycji

99 A. Kraushar, Towarzystwo Królewskie Przyjaciół Nauk. Ks. 3, Ostatnie lata 1828-1830, Warszawa 1905, s. 418-419.

100 „Gazeta Polska” 1831, nr 114 (28 kwietnia), s. 2; nr 231 (28 sierpnia); nr 234 (31 sierpnia). A. Patkowski, op. cit., s. 227. Oryginał listu znajduje się w Bibliotece Jagiellońskiej, sygn. 3685, t. 7, k. 131. 
literatury sowizdrzalskiej ${ }^{101}$. Na drugiej stronie karty tytułowej w Uwiadomieniu „Redaktor odpowiedzialny Bogdan Walka”"102 napisał: „, Tandeciarz« pismo czasowe będzie mieściło w sobie wszystko to, co inne pisma teraz wychodzące nie zawierają, czasem też i przestarzałe rzeczy. Poszyt arkuszowy na papierze zwyczajnym kosztuje gr 20". W zapowiadanej objętości ukazał się tylko numer pierwszy. Pozostałe miały po pół arkusza. W „Gazecie Polskiej” 30 kwietnia ukazała się nota podpisana przez Bogd[ana] Walkę, który informował, że pojedyncze numery kosztują $10 \mathrm{gr}$, a poszyt (tom) będzie zawierał 11 numerów i nabywać je można „we wszystkich księgarniach i składach pism czasowych”. Tę samą cenę umieszczano w ,Tandeciarzu” od piątego numeru ${ }^{103}$.

Ukazało się tylko 11 numerów. Na podstawie zamieszczanych w „Gazecie Polskiej" ogłoszeń udało się ustalić daty wydania siedmiu z nich: pierwszy z datą 2 stycznia 1831 ukazał się ok. 3 lutego, drugi — ok. 17 lutego, piąty — ok. 18 kwietnia, szósty — ok. 28 kwietnia, siódmy — ok. 30 kwietnia, jedenasty ok. 18 czerwca $^{104}$. Numer dziewiąty ukazał się przed 6 maja, zawiera bowiem informację o skazaniu na śmierć zamożnego szlachcica z Mazowsza, szpiega działającego na rzecz Rosji. Tego dnia ogłoszono odroczenie wykonania wyroku, ponieważ skazany zwrócił się do sejmu o prawo łaski. Natomiast w dziesiątym numerze opublikowano następującą wiadomość: „Redakcja »Tandeciarza« odwołuje doniesienie w nrze 9 pisma swego uczynione, jakoby jw. Rafał Cichocki, magnat powieszony został; nie było tak i nie będzie. Chciawszy jednego jw. powiesić potrzeba by i więcej; wszak to może się stać w wolniejszym czasie". Jest ona identyczna z wiadomością zamieszczoną w „Gazecie Polskiej” z dnia 17 maja, która jest pomniejszona o informację o możliwości wykonania wyroku w przyszłości ${ }^{105}$. Można z tego domniemywać, że dziesiąty numer ukazał się ok. 17 maja. W jedenastym numerze utwór pt. Przypadki pana Golenia nie ma zakończenia i został opatrzony informacją: „,dokończenie nastąpi” (s. 90). Wydawca „Tandeciarza" 30 kwietnia zapewniał czytelników, ,iż to pismo wychodzi i nadal będzie"106.

W czerwcu 1831 roku Ujazdowski naraził się bardzo, nie tylko władzom powstańczym, i najprawdopodobniej uznał kontynuowanie „Tandeciarza” za niemożliwe. Chodzi o krótki artykuł, zamieszczony w „Gazecie Polskiej” z 1 czerwca, informujący o wykonaniu kary śmierci na szpiegu rosyjskim Rafale Cichockim:

101 B. Wolska, op. cit., s. 182-183. Arcypaszkwil na Mickiewicza z 1848 roku ma podobny adres wydawniczy: „W Parzymiechach, czcionkami gęsimi...” — zob. Sensacje z dawnych lat, wyszukał i skomentował R. Kaleta, Warszawa 2009, s. 335.

$102 \mathrm{Na}$ ostatniej stronie numeru trzeciego, pod tekstem wydrukowano: „Redaktor odpowiedzialny B. Walka".

103 „Gazeta Polska” 1831, nr 116, s. 2.

104 "Gazeta Polska” 1831, nr 33 (4 lutego), s. 5; nr 47 (18 lutego); nr 103 (17 kwietnia), s. 2; nr 114 (28 kwietnia), s. 2; nr 117 (1 maja), s. 1; nr 132 (17 maja), s. 2; nr 163 (19 czerwca), s. 2.

105 „Tandeciarz” 1831, nr 9, s. 79; nr 10, s. 87; „Gazeta Polska” 1831, nr 132, s. 2.

106 „Gazeta Polska” 1831, nr 116. 
„Nie ma nic złego, co by na dobre nie wyszło”. Stare to polskie przysłowie sprawdziło się świeżo przez wstrzymanie egzekucyi wyroku nadzwyczajnego sądu wojennego stałego w sprawie Rafała Cichockiego. Gdyby ten zdrajca kraju (bo go tylko za takiego późniejszy wyrok uznał) zaraz był powieszonym, jako prosty szpieg, egzekucja nie byłaby sprawiła takiego wrażenia, jakie się onegdaj przy traceniu go objawiło. Choć nie obwieszczono, że egzekucja ma nastąpić, tłumy ludu zgromadziły się po ulicach, przez które był prowadzonym. Lud wyraźnie okazywał oburzenie na widok możnego wyrodka, pluł itd. Młody kat, choć pierwszy raz, wybornie się spisał. Przytomni jeńcy moskiewscy poklaskiwali temu aktowi i podzielali powszechną radość ludu. Krzyczano nawet: ,,a protektorowie?” Ale co najpożyteczniejsza: że przybyli z dalekich stron wieśniacy, wróżyli sobie stąd bliskie nadejście dobrych czasów, kiedy „panów” zaczęto wieszać. Bodaj się nie zawiedli! T.U.

Wydaje się, że sprawa Rafała Cichockiego była bez precedensu w czasie całego powstania. Złapany przez oddział powstańczy w czasie ataku na ariergardę rosyjską, został przekazany Sądowi Wojennemu Nadzwyczajnemu przez gubernatora Warszawy. Sąd 2 maja skazał go na śmierć za zdradę oraz udzielanie pomocy wojskom rosyjskim i zaopatrywanie ich w żywność. Na posiedzeniu Sejmu, w dniu 5 maja, poseł z powiatu stanisławowskiego (w tymże powiecie były dobra Cichockiego), Szczepan Swiniarski, zakwestionował wyrok sądu. Uważał, że oskarżonemu udowodniono tylko dostarczanie Rosjanom zaopatrzenia i czerpanie $\mathrm{z}$ tego zysku, co powinien sądzić sąd kryminalny. Konsekwencją było zawieszenie w dniu 6 maja przez rząd wykonania wyroku. Na sesji sejmu 16 maja rząd przedstawił dokumenty sprawy i ich prezentację zakończył wnioskiem o prawo łaski dla skazańca, wyrażając przy tym swoje przekonanie, że nie jest on jej godzien. Dyskusja w sejmie trwała dwa dni. Decyzję, który sąd winien w sprawie Cichockiego orzekać - Nadzwyczajny Sąd Wojenny czy Wojewódzki Sąd Wojenny - pozostawiono rządowi. W dniu 21 maja Wojewódzki Sąd Wojenny potwierdził poprzedni wyrok, rząd ponownie przedstawił sejmowi dokumenty sądowe i znów rozgorzała dyskusja nad aspektami humanitarnymi tej sprawy. W głosowaniu 34 posłów, deputowanych i senatorów było za udzieleniem łaski, a 55 było temu przeciwnych. Wyrok został wykonany 30 maja przez publiczne ścięcie w Warszawie za Rogatkami Jerozolimskimi ${ }^{107}$.

Publikacja Ujazdowskiego została odczytana przez władze jako wezwanie ludu do buntu. Wódz naczelny, generał Jan Skrzynecki, żądał od rządu ukarania autora i zapobieżenia takim przypadkom na przyszłość przez wprowadzenie przepisów o cenzurze. Sam zaś wezwał redaktora „Gazety Polskiej”, Jana Nepomucena Janowskiego, na rozmowę, w czasie której groził mu rozstrzelaniem. Redaktor bronił się, powołując się na przyjętą przez „Gazetę” zasadę gościnności, przedstawioną na jej łamach w kwietniu 1831 roku. Wiceprezydentowi Warszawy Janow-

107 Dyaryusz Sejmu z r. 1830-1831, wyd. M. Rostworowski, Kraków 1909-1910, t. 3, s. 311312, 475, 489-536; t. 4, s. 53. „Gazeta Polska” 1831, nr 123, 126; „Polak Sumienny” 1831, nr 129, 133, 143, 155; „Nowa Polska” 1831, nr 145; „Powszechny Dziennik Krajowy” 1831, nr 96, 121, $135,136,140,145$. W opinii posłów rząd, powołując w marcu sądy wojenne, nie doprecyzował zakresów ich kompetencji. 
ski wyjaśnił: „Artykułu w mowie będącego jest autorem p. Ujazdowski, obywatel w województwie podlaskim; miejsce zamieszkania jego nie jest mi wiadomym; doręczony mi został przez brata jego rodzonego, wydawcę niegdyśs »Pamiętnika Sandomierskiego «"108. Ta sama zasada gościnności pozwoliła redakcji 5 czerwca zamieścić kolejny nadesłany artykuł, w którym autor wyraził zdziwienie, że w „Gazecie” ukazał się ,artykuł dwuznacznemu ulegający tłumaczeniu”109.

„Nowa Polska”, dotąd najbardziej radykalna gazeta reprezentująca Towarzystwo Patriotyczne, 5 czerwca w obszernym artykule wytknęła „Gazecie Polskiej” opublikowanie materiału Ujazdowskiego, który „sprawiedliwie zasmucił przyjaciół prawa, publicznej spokojności i naszej rewolucji”. Przedłużanie się rozstrzygnięcia sprawy Cichockiego tłumaczono następująco: „Chciano tylko zachowania form, chciano najsumienniejszego wymiaru sprawiedliwości, chciano uniknąć podejrzeń, że obwiniony padł ofiarą namiętności, zaburzeń, rewolucji; chciano nieszczęśliwemu okazać wszelką łagodność, wszelką obronę, wszelką ludzkość, chciano sprawiedliwości nie zemsty". W zakończeniu artykułu z zadowoleniem stwierdzono: „To nas pociesza tylko, że głos rozsiewający namiętności, do żadnej nie przemówił duszy, że jest silnym publiczny rozsądek i sumienie narodu". Obywatel W. A. pochwalił w „Powszechnym Dzienniku Krajowym” „Nową Polskę” za „zmianę w sposobie pisania” — „szczególniej trafił do przekonania przyjaciół porządku artykuł o Rafale Cichockim"110.

Miał Tomasz Ujazdowski, o czym myśleć, oddając do druku jedenasty numer „Tandeciarza”. Być może już wcześniej zamierzył zająć się popularyzacją publicystyki politycznej sprzed kilkudziesięciu lat, np. Sejmu Wielkiego. Równocześnie bowiem „Gazeta Polska” zawiadamiała czytelników w dniu 19 czerwca o ukazaniu się jedenastego numeru „Tandeciarza” i broszury Gabriela Taszyckiego Projekt wiecznego bezkrólewia w roku 1790 pierwszy raz przez Pewnego do druku podany, a teraz odnowiony z przedmową Ujazdowskiego ${ }^{111}$.

„Gazeta Polska” towarzyszyła „Tandeciarzowi” od pierwszego numeru. Nawiązując prawdopodobnie do sprawy Cichockiego, zauważyła, że wyrok śmierci wydany na biskupa Wojciecha Skarszewskiego, jako targowiczanina, podpisał generał Józef Zajączek (w powstaniu 1794 roku prezes Sądu Kryminalnego Woj-

108 Janowski wspominał, że zgromadzeni na egzekucji Cichockiego ,wieśniacy wróżyli sobie bliskie nadejście dobrych czasów skoro i panów, przyjaciół Moskali śmiercią karzą" - zob. J.N. Janowski, op. cit., s. 198-203. A. Kraushar, Wolność druku i dziennikarstwo warszawskie w czasach listopadowych (1830-1831), Warszawa 1909, s. 45-48.

109 „Gazeta Polska” 1831, nr 149. Nie była możliwa pogoń za autorem artykułu, bo Podlasie było w rękach Rosjan.

110 „Nowa Polska” 1831, nr 149; „Powszechny Dziennik Krajowy” 1831, nr 157, s. 1008.

111 „Gazeta Polska” 1831, nr 163; „,Kurier Polski” 1831, nr 545, s. 860; [G. Trzciński], Projekt wiecznego bezkrólewia w r. 1790 pierwszy raz przez Pewnego do druku podany, edycya druga, Warszawa 1831, w ciskarni Rylla, nakładem wydawcy. Pierwsze wydanie broszury Ujazdowski darował Towarzystwu Przyjaciół Nauk w 1829 roku — zob. AGAD, TPN, 73, s. 19. 
skowego), który po latach „pod rządem moskiewskim stanął na czele rządu kraju” (w 1815 roku został namiestnikiem Królestwa Polskiego), a biskup stanął „,na czele duchowieństwa" (w 1824 roku został arcybiskupem warszawskim i prymasem Polski). Informując o ukazaniu się szóstego numeru „Tandeciarza”, zauważono, iż o piśmie tym można „powiedzieć mianowicie co do działu »Nowiny«, że »ridendo castigat more«. Często po staroświecku, ale prawdę mówi”. Trzy dni później „Gazeta” przedrukowała z siódmego numeru, z działu „Nowin”, zamieszczoną tam anegdotę ${ }^{12}$. Jako artykuł nadesłany zamieściła redakcja „Gazety” następujące doniesienie (podpisane: „Ks. Bogdan Walka”): „Pewien wysoki urzędnik dla pomnożenia dochodów skarbowych, tyle potrzebnych w teraźniejszym położeniu kraju, proponuje ustanowić podatek od wszystkich wiktuałów do stolicy wprowadzanych. Nie zbijam tego projektu, bo sądzę, że niedorzeczność jego aż nadto jest widoczną i najlepszemu umysłowi dościgłą; ale proponuję z mej strony, ażeby nałożyć podatek na wszystkie głowy, w których się podobne projekta lęgą"113.

Powiadamiając czytelników o ukazaniu się ostatniego, jedenastego numeru „Tandeciarza”, redakcja „Gazety” przedrukowała wszystkie wiadomości z działu „Nowin”. Jeszcze raz redakcja sięgnęła do ostatniego numeru tego czasopisma 9 sierpnia, w czasie rosnącego niezadowolenia społeczeństwa z powodu braku stanowczych działań wojskowych przeciw zbliżającej się do Warszawy armii rosyjskiej. Przedrukowano wówczas wiersz Zajączkowi, komendantowi Pragi w d. 4 listopada 1794 r. Przypomniano w nim generała, „Co najpierwszy przed wschodem słońca uciekł z Pragi” i „Oddał na rzeź to miasto i skrył się w Warszawie”114.

Dział „Nowiny” wypełniały krótkie formy informacyjno-satyryczne, najczęściej były to satyryczne doniesienia prasowe, czasem anegdoty, scenki rodzajowe lub sposobem katechizmowych - pytania i odpowiedzi ${ }^{115}$. W tym dziale Ujazdowski starał się wykorzystywać aktualne wydarzenia, np. w numerze drugim (ukazał się ok. 15 lutego) znajduje się rozmowa: „, Gdzie też najwygodniejsza łaźnia? Pytał Moskwicin Niemca. Jak dla was Moskali w Warszawie, odpowiedział drugi. Dwa razy wam sprawiono łaźnię w tym mieście, a teraz Dybiczowi po trzeci raz sprawią". W następnym numerze znalazły się dwa doniesienia o tej wyprawie: „Wyprawa Moskali na Warszawę nie udała się podług pierwszego planu Dybicza, przecież nie bez korzyści, bo do tytułów licznych przybrał jeszcze »Waldmarschal«”. I drugie: „W Warszawie mówią: po d. 25 lutego r. b. Dybicz w Moskwie »Dybiczem«, w Turcji »biczem«, w Polsce »niczem«" $" 116$. Były to doniesienia przed i po bitwie grochowskiej. Gdy w I połowie marca opublikowano w prasie odnaleziony list profesora historii Uniwersytetu Warszawskiego

112 „Gazeta Polska” 1831, nr 33, s. 5; nr 114 (28 kwietnia), s. 2; nr 117 (1 maja), s. 1; „Tandeciarz" 1831, nr 7, s. 63-64.

113 „Gazeta Polska” 1831, nr 136 (21 maja), s. 3-4.

114 „Gazeta Polska” 1831, nr 213, s. 2-3; „,Tandeciarz” 1831, nr 11, s. 93.

115 B. Wolska, op. cit., s. 192.

116 „Tandeciarz” 1831, nr 3, s. 31; nr 4, s. 39. 
Augusta Ernesta Zinserlinga ${ }^{117}$ do Nikołaja Nowosilcowa, w którym proponował pomoc w reakcyjnej reformie szkolnictwa w Królestwie Polskim, w „Tandeciarzu” poinformowano publiczność: „Pewien profesor Niemiec, tak się do ojczyzny naszej przywiązał, iż w 30 latach pobytu i urzędowania dotąd nie mówi po polsku. Przeszły rząd, wynagradzając jego zasługi, obsypał go pieniędzmi i mianował członkiem honorowym towarzystwa elementarnego. Zacny profesor powróciwszy z Warszawy [do Niemiec] oświadczył uczniom: iż Komisja Oświecenia wzięła go za »członek honorowy«"118.

Wśród wielu osób „wyróżnionych” w „Tandeciarzu” znalazł się też rektor szkoły wojewódzkiej w Kielcach, Andrzej (Kasper) Polejowski (1776-1849), który kilka lat wcześniej dał się Ujazdowskiemu mocno we znaki: „»Kto się poniża będzie podwyższon«, właśnie też obywatele w Kielcach chcieli rektora podwyższyć, za to, iż się »zbyt poniżał« za przeszłego rządu". Tego typu wiadomości zamieszczał nie tylko „Tandeciarz”. W „Gazecie Polskiej” znalazło się doniesienie: „Redaktor Biblioteki Chrześcijańskiej ma ofiarować tyle tysięcy złp na ołtarz ojczyzny, ile tomów wyszło wspomnianego pisma. Będzie to tylko zwrócony grosz i to bez procentu" 119 . Podobne anonse znalazły się także w "Nowej Polsce” i „Powszechnym Dzienniku Krajowym”120.

W ostatnim numerze „Tandeciarza” zamieszczono wiadomość: ,Już to drugi Skrzynecki, jako jenerał, walczy za niepodległość Polski przeciw Moskwie; co pierwszy nie mógł to drugi dokona". Nie wydaje się, by Ujazdowski w ten sposób wyraził swe nadzieje związane z osobą naczelnego wodza, który dwa tygodnie wcześniej groził rozstrzelaniem redaktorowi „Gazety Polskiej” za niewielki artykuł o wykonaniu wyroku na Rafale Cichockim. Jest to raczej przypomnienie wodzowi o jego podstawowym obowiązku ${ }^{121}$.

Dział „Rzeczy dawniejsze” w numerze pierwszym rozpoczynał paszkwil z czasów targowicy Afisz na benefis Szczęsnego Potockiego i sentencja wyroku Sądu Kryminalnego Wojskowego na innego targowiczanina, biskupa Wojciecha Skarszewskiego, z dnia 11 września 1794 roku. Wyrok razem z Uwiadomieniem względem zmiany kary śmierci na karę wiecznego więzienia przejęto z prasy war-

117 August Ernest Zinserling (1780-1844), filolog klasyczny, profesor Uniwersytetu Warszawskiego od 1817 roku. Do Warszawy przybył z Hamburga w 1816, rok uczył w Liceum Warszawskim. Od 1832 roku w Petersburgu.

118 „Tandeciarz” 1831, nr 6, s. 56.

119 Serię wydawniczą „Biblioteka Chrześcijańska” redagował Modest Watt Kosiński, sekretarz Dyrekcji Wychowania Publicznego i cenzor, podwładny J.K. Szaniawskiego. W latach 1827-1828 ukazało się co najmniej osiem tomów. W pierwszych trzech tomach w 1827 roku znalazł się Katechizm rzymski. „Bibliotekę” drukowano w Drukarni Szkolnej KRWRiOP, której redaktor zwracał tylko koszt robocizny.

120 „Tandeciarz” 1831, nr 2, s. 24; „Gazeta Polska” 1831, nr 53, s. 3. Na przykład: o Rożnieckim w „Powszechnym Dzienniku Krajowym” (nr 38, s. 151), o sekretarzu generalnym KRWRiOP (Edward Rakiety) w „Nowej Polsce” (nr 13).

121 „Tandeciarz” 1831, nr 11, s. 95; B. Wolska, op. cit., s. 201. 
szawskiej z czasu powstania, ale pominięto wiadomość o degradacji kościelnej skazanego biskupa $\mathrm{w}$ dniu 13 września ${ }^{122}$. Temat zdrady kraju był aktualny przez cały czas powstania, a przypomnienie targowicy zwracało uwagę na ludzi, którzy gorliwie służyli Rosjanom przed powstaniem. Do tematu zdrady powrócił Ujazdowski, drukując wiersz Przekleństwo narodu zlane na zdrayców Oyczyzny, w którym autor próbował wyliczyć, ile „nieszczęść niech wszyscy zdrajcy kraju życzą”. Znalazło się tam również swoiste dopowiedzenie: „Książę, hrabia, graf, baron, szlachcic i pankowie orderowi (wyjąwszy krzyże wojskowe), kto się tych urojonych godności sam dobrowolnie nie zrzecze a nie przybierze tytułu obywatela, jest przeciwny naszej wolności, równości i niepodległości; kto zaś temu przeciwny powinien dla szczęścia ludów wisieć" ${ }^{\prime 23}$. I dodawał w przedostatnim numerze: „Co jest rewolucja? - pytał Krakus Warszawiaka. Jest to wieszanie panów. - Jak często rewolucja bywa? Co kilkadziesiąt lat. — Czy pamiętasz przeszłą rewolucją? Pamiętam tak dobrze jak Jubileusz, za mojej pamięci już druga. —Kiedy też więcej powieszono lub stracono panów? W pierwszej, teraz żaden książe nie wisiał — wtenczas nawet biskupi i panowie gwieździści!"”24

Na wieść, że Edward Raczyński rozpoczął w Berlinie starania o pośredniczenie Prus między Rosją a władzami powstańczymi, Ujazdowski napisał: „Śmierć tym wszystkim, którzy Brandenburczyka za pośrednika mieć chcą!”125 Dla zrównoważenia wrażenia wywołanego w numerze pierwszym przywołaniem zdrajców targowickich, Szczęsnego Potockiego i Wojciecha Skarszewskiego, zamieścił Ujazdowski wezwanie Do Sandomierzanów z 1794 roku, w którym apelowano, aby szlachta — „obywatele”- z bronią w ręku stanęła na chłopstwa czele: „Mówcie do nich jak do ludzi »Współ Bracia! Obywatele! Niech w Was Wolność krew obudzi [...] Skoro niewolnik zobaczy, Co są wolności obrońce, Co może Polak w rozpaczy Nie ujrzy go drugie słońce «". Drugi wiersz Pieśń huzara węgierskiego z kampanii w r. 1809 jest relacją austriackiego żołnierza o dzielności polskich ułanów w czasie tej wojny, opowiedzianą śmieszną, łamaną polszczyzną ${ }^{126}$. W dalszych numerach Ujazdowski kontynuował publikację utworów z literatury politycznej II połowy XVIII wieku, głównie z czasu Sejmu Wielkiego, targowicy. Były to: Katechizm polski, Ewangelia, Krytyka, O Królu Stanisławie Auguście Poniatowskim (trzy krótkie wiersze, w tym: „Dwiem przysięgi wykonał, obydwiem przełamał...”), Na Marszałka Gurowskiego. Spraw aktualnych dotyczy tylko jeden utwór: Nowy zwiazek na obronę Ojczyzny po nastapionem armistitium pod hastem Króla Faraona w wojsku uczyniony takowy. Po zawieszeniu broni „partia

122 „Tandeciarz” 1831, nr 1, s. 3-12; „Gazeta Wolna Warszawska” 1794, dodatek do nr 42 (16 września), s. 550-551.

123 „Tandeciarz” 1831, nr 3, s. 26-29; nr 4, s. 33-36, 39.

124 „Tandeciarz” 1831, nr 10, s. 87. Rok jubileuszowy, rok święty obchodzono w Kościele katolickim w 1825 roku.

125 „Tandeciarz” 1831, nr 4, s. 38.

126 „Tandeciarz” 1831, nr 1, s. 12-15. 
gorliwych Polaków o swoje starająca się dobro przedsięwzięła ostatnich szukać środków zemszczenia się nad Moskwą i ze swej strony armią uformowawszy, postanowiła na krok jeden nieprzyjacielowi nie ustąpić”. W 18 punktach spisano organizację armii, przydzielając stanowiska dowódcze od dowódcy dywizji do zakrystiana obozowego. Problematykę polską w szerszej perspektywie europejskiej przedstawiono w wierszu Dwie trójce 1827. Satyra na trójcę zaborców Polski, której działania przeciwstawia boskiej Trójcy: „Jedna Trójca ta co w niebie,/ Druga tu na ziemi,/ Czcijmy obie choć do siebie/ Nie są podobnemi”. Dopełnieniem i poszerzeniem prezentowanej w „Tandeciarzu” problematyki politycznej jest przekład poematu satyrycznego Wiek brazu George’a Byrona. Tłumaczenia prozą dokonał dla swego pisemka najprawdopodobniej sam Ujazdowski. Utwór napisany na przełomie 1822 i 1823 roku, po kongresie Świętego Przymierza w Weronie, bardzo ostro rozprawiał się z poczynaniami reakcyjnych rządów w Europie. Są w nim fragmenty dotyczące Polski, np. „O ty Ojczyzno Kościuszki, pamiętna krwawego długu nie opłaconego jeszcze Katarzynie! Polsko przez którą przeszedł Anioł zemsty, ale porzucił jak zastał w gruzach, zapominając o twych zgwa[ł] conych prawach, porozebranym ludzie i zatraconym nazwisku, wzdychaniu do wolności i łzach długo płynących. Brzmi dotąd w uszach tyranów ten groźny okrzyk »dalej, dalej Kościuszko«, dyszy jeszcze w wojennej ochocie pragnienie krwi niewolników i Carów"127.

W numerze trzecim „Tandeciarza” znajduje się Wiersz Góreckiego pod Statuq Jana III. napisany. Antoni Górecki napisał go podczas obrad kongresu wiedeńskiego i zakończył wezwaniem:

Bracia do broni! Czyż Wam krwi nie stało,

Gdy umieramy, umierajmyż z chwałą;

Przynajmniej kiedyś będzie pomnik słyną:

Tu był Lud Polski, co za wolność zginą1128.

Obok satyry politycznej w „Tandeciarzu” znajdują się utwory krytykujące dawne polskie obyczaje. W końcu XVIII wieku ważne było pytanie: co przyczyniło się do upadku państwa - trwanie przy starych zwyczajach czy przyjmowanie nowych? Poszukiwanie odpowiedzi znajdujemy w Żalach Podstolego do Skarbnika nad zepsuta Młodzieżą, a także w zamieszczonym w dziale „Nowiny” obrazku, w którym „Polak sensat” krytykuje w sejmie posłów za ich nowe stroje i poniechanie dawnych sposobów obradowania. Te odwiedziny w sejmie powstańczym to gwałtowny atak na „owo polladium złotej czy tylko pozłacanej szlacheckiej wolności, za jakie był uważany przedrozbiorowy sejm — zwyrodniały okaz polskiego parlamentaryzmu"129.

127 „Tandeciarz” 1831, nr 6, s. 55.

128 „Tandeciarz” 1831, nr 3, s. 26.

129 „Tandeciarz” 1831 , nr 2, s. 17-21; nr 3, s. 25-26; nr 7, s. 63-64. A. Zieliński, op. cit., s. 150 . 
Wyjęte z XVII-wiecznego rękopisu Dictionarium Latino Polonicum seu Calepinus Aulicus i datowane przez Ujazdowskiego na 1640 rok jest pamfletem na wyższe sfery społeczne, które używały bardzo przewrotnego moralnie języka ${ }^{130}$. Niedokończony utwór Przypadki pana Golenia, którego akcja dzieje się w Rzeczypospolitej po pierwszym rozbiorze, jest ostrą satyrą na ówczesne sądownictwo polskie i religijność społeczeństwa. Piotr Goleń został niesłusznie oskarżony o arianizm. Jego przyjaciel, chcący mu pomóc, miał poważny problem: „Że Piotr nie był arianinem dobrze wiedziałem, ale że bluźnił, co? jak? kiedy? gdzie? przy kim?... trudno było mi wiedzieć, a pytać się ani sposobna, usprawiedliwiać go, było to samo, co być bluźniercą"131. Brak zakończenia opowiadania pozostawia czytelnika z powyższymi pytaniami.

Ujazdowski zwalczał jezuityzm i fałszywą religijność. Krytykował duchowieństwo polskie, szczególnie wyższe i kongregacje religijne, a zwłaszcza misjonarzy, jezuitów, kapucynów za ich niechętny stosunek do powstania. Swoje poglądy religijne w połączeniu ze sprawami społecznymi przedstawił w następującym tekście:

Wielu jest bogów, pytał Niemiec Francuza, dwóch odpowie zapytany, Bóg despotów i Bóg ludów. Pierwszego nazywamy inaczej bogiem ciemności, intryg, tyraństwa, oszustwa, jezuityzmu, szpiegostwa itd. Ten bóg odbiera nakadzenia, ukłony; słucha z ukontentowaniem Te Deum Laudamus za morderstwo tysięcy ludzi itp. nigdy nie karze despotów a cieszy się z wytępienia człowieczeństwa. Bóg ludów, jest bez namiętności, nie zna despotów i arystokratów — łagodny, dobry, nie mściwy; kapłanami jego są ludzie cnotliwi, oświeceni, wolni, dziećmi ukochanymi wszystkie narody. Bóg ten nie ma nieba, ale założyt mięszkanie między narodami ${ }^{132}$.

Dawne utwory XVII- i XVIII-wieczne opublikowane w „Tandeciarzu” uzyskały w czasie powstania nowe odczytanie i rozumienie, np. krótki wiersz pisarza politycznego z przełomu XVI i XVII wieku, działacza rokoszu Zebrzydowskiego przeciw królowi Zygmuntowi III, pt. Wyznanie polityczne wiary Jana z Fulsztyna Herburta r. 1606:

Ojczyzno moja droga! Ojczyzno kochana!

Jeśli królem despotą masz być ukarana;

Niech ci raczej tureckie panują miesiące,

Niż orły w czarnych szponach jarzmo trzymające.

Bo nie sromota zginąć z nieprzyjaciół ręki;

A lepsza śmierć od razu, niźli długie męki...133

130 „Tandeciarz” 1831, nr 5, s. 44-46; Biblioteka Narodowa, BOZ 1162. J. Czubek w wydanych przez siebie Pismach politycznych z czasów rokoszu Zebrzydowskiego (T. 2, Proza, Kraków 1918, s. 78) przypisał Dictionarium czasom tego rokoszu.

131 „Tandeciarz” 1831, nr 10, s. 81-86; nr 11, s. 89-90, cyt.: s. 90.

132 „Tandeciarz” 1831, nr 9, s. 80.

133 „Tandeciarz” 1831, nr 5, s. 40. 
W ostatnim numerze niespodzianką są Ulotne poezye Molskiego do Malinowskiego $^{134}$ — trzy wierszyki o przyjacielskich zabawach poety Marcina Molskiego z biskupem Antoninem Malinowskim. Być może na ich miejscu miał być inny tekst, który w ostatniej chwili został wycofany.

Do „Tandeciarza” Ujazdowski z XVIII-wiecznej literatury politycznej wybierał satyry i paszkwile polityczne skierowane „przeciwko rosyjskiej gwarancji i ingerencji Rosji w wewnętrzne sprawy Rzeczypospolitej, ostro piętnujące zdrajców stojących na jej usługach i innych rodzimych reakcjonistów". Przywoływał historyczne przykłady, aby ostrzec przed niebezpieczeństwami. Redaktor pisma „,żywo angażujący się w sprawy narodu” dostrzegł w utworach z ostatnich lat Rzeczypospolitej ich ponowną przydatność i aktualność polityczną. Tworzyli je ludzie z różnych ugrupowań politycznych tamtych czasów, a „tym, co je łączy, jest konkretność adresu satyrycznego, nieubłagany stosunek do zdrajców wszelkiego autoramentu oraz do Rosji brutalnie ingerującej w wewnętrzne sprawy kraju. Poza tym szczególnie w dziale informacji satyrycznej, wyraźne są ślady tradycji jakobińskiej, do której nawiązywała lewica powstania listopadowego""135.

„Tandeciarz” przynosił czytelnikowi dokumenty świadczące, że w czasach rozbiorów byli Polacy, którzy przyczynili się do gwarancji ustroju przez Rosję, Prusy i Austrię oraz stałej ingerencji rosyjskiej w wewnętrzne sprawy Rzeczypospolitej. Byli zdrajcy i oportuniści. Ujazdowski ostrzegał, aby ta sytuacja nie powtórzyła się w czasie powstania. Doborem tekstów historycznych „Tandeciarz” różnił się od „Pamiętnika Sandomierskiego”, o czym zadecydowały przede wszystkim bieżące względy polityczne ${ }^{136}$.

\section{INNE PRACE NAUKOWE I REDAGOWANIE „ROZMAITOŚCI KRAKOWSKICH”}

Równocześnie z jedenastym numerem „Tandeciarza” w połowie czerwca 1831 roku ukazało się wznowienie broszury Gabriela Taszyckiego z 1790 roku pt. Proiekt wiecznego bezkrólewia. Tomasz Ujazdowski opatrzył ją przedmową i wydał własnym kosztem. Broszura ta najwidoczniej zainteresowała publiczność, skoro już w połowie lipca Ujazdowski ponowił jej wydanie ${ }^{137}$. Redakcja „Gazety Polskiej” 17 lipca obiecała „,udzielić czytelnikom swoim szczegółowego rozbio-

134 „Tandeciarz” 1831, nr 11, s. 93-94.

135 B. Wolska, op. cit., s. 198-199.

136 Historyk polskiego czasopiśmiennictwa A. Słomkowska napisała: „»Tandeciarz« niezwykle radykalne pismo satyryczne, w którym znajduje się nawet aluzyjny apel do «wieszania panów «" (Rola „,Gazety Polskiej” w okresie powstania listopadowego, „Rocznik Historii Czasopiśmiennictwa Polskiego" 1, 1962, s. 99).

137 [G. Taszycki], Projekt wiecznego bezkrólewia w roku 1790 pierwszy raz przez Pewnego do druku podany, a teraz odnowiony, edycja druga, Warszawa 1831, s. [5], 74; [idem], Projekt wiecznego bezkrólewia w roku 1790 pierwszy raz przez Pewnego do druku podany, a teraz odno- 
ru tego interesującego pisma”, ale obietnicy nie spełniła, jedynie Ksawery Bronikowski w wydawanym przez siebie „Wolnym Polaku” zamieścił przedmowę Ujazdowskiego do broszury Taszyckiego ${ }^{138}$.

W przedmowie obszernym cytatem przypomniał Ujazdowski posła Sejmu Wielkiego Wojciecha Turskiego, który mówił o republikanizmie polskim i ostrzegał: „Z pogrzebem Rzeczypospolitej pogrzebiemy wszystkie wspomnienia wielkie!... Potomkowie bohaterów, obrońców niegdyś wolności i swobód Rzeczypospolitej staną się narzędziem despotyzmu: ich majątki i zbytki mogą się powiększyć, bo prawość i cnota $\mathrm{z}$ ich serca znikną". Jako motto przedmowy wydawca umieścił wyżej cytowany wiersz Jana Herburta. Celem, który mu przyświecał przy wznowieniu pracy Taszyckiego, było: „Żeby wykazać ludziom łatwowiernym a przypomnieć światłym, postanowiłem przedrukować niniejsze dzieło; jest ono szczupłe co do objętości, ale wielkie, nieocenione, co do istoty rzeczy" i ,aby wywieść z błędu tych, którzy lękają się wolnych rządów, nam tak właściwych, Rzeczypospolitej”.

G. Taszycki krytycznie przedstawił dzieje polskiej demokracji szlacheckiej i władzy królewskiej. Posiłkował się wiedzą o historii ustroju demokratycznego i monarchicznego w różnych krajach. Skrytykował projekt starań o ustanowienie w Polsce monarchii dziedzicznej, w ogóle monarchię i działania magnaterii. Proponował dla Polski nowe rozwiązania ustrojowe. Bliskie były mu idee Jana Jakuba Rousseau. Zakończył swe rozważania cytatem z Michela de Montaigne'a: „prawo najgorsze jest lepsze, niż pan najlepszy, bo każdy pan siebie nade wszystko przekłada, a prawo nikogo".

Po upadku powstania listopadowego i przeniesieniu się do Krakowa Ujazdowski w 1834 roku podjął pracę redaktora niedzielnego dodatku do „Gazety Krakowskiej” pt. „Rozmaitości Krakowskie”. Redakcja „Gazety” 28 grudnia 1833 roku zamieściła $\mathrm{w}$ swym piśmie zapewnienie, że w następnym roku będzie taki dodatek wydawać, wyjaśniając: „Niektóre ulepszenia z d. 1 stycznia nastąpią. Raz na tydzień będzie dołączane pismo pod tytułem »Rozmaitości Krakowskie«. Prenumeratorowie »Gazety《 »Rozmaitości« bezpłatnie otrzymają jako dodatek. Wiadomości brukowe i lekkie — mody dla obojga płci, rozmaite powiastki i rady dla gospodyń tu znajdą miejsce"139.

Dzień przed ukazaniem się numeru pierwszego „Rozmaitości”, 4 stycznia (sobota), zawiadomiono publiczność, że „w niedzielę o godzinie $12 \mathrm{w}$ południe czytelnicy Gazety Krakowskiej odbiorą" go. Już w pierwszych tygodniach ujawniły się trudności z dostarczaniem nowego pisma czytelnikom. Dlatego 23 stycznia informowano:

wiony, edycja trzecia, Warszawa 1831. Autora broszury wskazał W. Smoleński w pracy pt. Publicyści anonimowi z końca XVIII wieku, Warszawa 1912, s. 7-8, 55-56.

138 „Gazeta Polska” 1831, nr 190. „Wolny Polak. Pismo Treści Politycznej i Historycznej” 1831, nr 2, s. 82-86. Numer ten ukazał się ok. 10 lipca.

139 „Gazeta Krakowska” 1833, nr 342 (28 grudnia), s. 1187, ogłoszenie powtórzono dwa dni później w numerze 344, s. 1193. 
Redakcja Gazety Krakowskiej zawiadamia mających chęć prenumerowania, że pierwszych numerów Gazety ani Rozmaitości nie odbiorą, to z przyczyny, iż tyle odbija się egzemplarzy, ilu jest prenumeratorów. - Rozmaitości nr 1szy wielu już nie otrzymało; w miarę jednak przybywania czytelników postara się Redakcja o przedrukowanie n[umer]ów tych, na których będzie zbywało. Przy tej sposobności ma zaszczyt wydawca donieść, iż pod jego redakcją Gazeta Krakowska od d. 1 listopada r. z. wychodzi. Wszystkie zatem błędy, uchybienia itd. po dzień dzisiejszy doń należą.

Przyczyna braku egzemplarzy tkwiła w opóźnieniach zamówień składanych w urzędach pocztowych, szczególnie w Królestwie Polskim. O zaległych numerach abonujący dowiedzieli się 17 marca, że „niebawnie będą mieli doręczone”"140.

Tytuł pisma nawiązywał do nieregularnie pojawiającej się od początku 1832 roku w „Gazecie Krakowskiej” rubryki „Rozmaitości”. Prospekt na wydawanie nowej Gazety Krakowskiej ogłoszony 20 grudnia 1831 roku przewidywał: „I. Część urzędowa; II. Część nieurzędowa. III. Rozmaitości”.

Trzeci ten oddział nowej Gazety Krakowskiej zabawie z pożytkiem czytających poświęcony, staraniem Redakcji będzie, ażeby zawsze mógł być interesownym i w miarę więcej lub mniej ważnych wiadomości politycznych, więcej lub mniej ważnych wiadomości obszernym. — Płody młodej literatury i poezji, bez żadnej jednak pod najmniejszym względem politycznej dążności, wyłącznie tylko zabawę, moralność i naukę na celu mieć mogące; recenzje nowych dzieł naukowych i literackich lub wiadomości o tychże; wiadomości o nowych wynalazkach użytecznych; lekkie i dowcipne rzeczy wolne od wszelkiej polemiki stanowią osnowę tej części nowej Gazety Krakowskiej $^{141}$.

Zmiana redakcji na przełomie października i listopada 1833 roku spowodowała zmiany w rubryce „Rozmaitości”. W pierwszym listopadowym numerze znalazła się anegdotyczna wiadomość O Kominiarczyku Królewskim Stanisława Augusta. Dwa tygodnie później ukazał się list osiemdziesięcioletniego arianina Aleksandra R. zmuszonego opuścić Polskę po uchwałach sejmowych 1658 i 1659 roku o przymusowym wydaleniu z kraju arian lub ich przejściu na katolicyzm ${ }^{142}$. Dalej informowano czytelników o kupnie poloniców przez króla duńskiego Fryderyka VI, zamieszczono anegdotyczną relację o powitaniu króla Jana III Sobieskiego w mieście Liwie, aby zaś umożliwić czytelnikom porównanie Francji XIX-wiecznej z XVI-wieczną, przygotowano artykuł na podstawie książki Jana Bofera Benesiusza Relatie powszechne abo nowiny pospolite (tłumaczył z włoskiego Paweł z Łęczycy, Kraków 1613) ${ }^{143}$. Takich materiałów

140 „Gazeta Krakowska” 1834, nr 3, s. 12; nr 18, s. 69; nr 63, s. 249-250.

141 Prospekt na wydawanie nowej Gazety Krakowskiej podpisał Stanisław Gieszkowski, redaktor, wydawca i drukarz „Gazety Krakowskiej”, która od 2 stycznia 1832 do 31 października 1833 roku miała tytuł: „Codzienna Gazeta Krakowska”.

142 „Gazeta Krakowska” 1833, nr 289, 302. List arianina, pochodzącego z Kujaw, żołnierza wojen w obronie Polski i Austrii za cesarza Rudolfa II, według wydawcy był adresowany do Olbrychta Karmanowskiego, poety, który wówczas już od ponad dwudziestu lat nie żył.

143 „Gazeta Krakowska” 1833, nr 328, s. 1138-1140; nr 334, s. 1161-1162; nr 335, s. $1165-$ 1166. 
dotyczących narodowej historii dotąd w „Gazecie Krakowskiej” nie zamieszczano i wskazują one na współpracę redakcji z Tomaszem Ujazdowskim.

Prenumerata kwartalna kosztowała 3 zł. Warszawski „Dziennik Powszechny" zawiadomił swych czytelników o nowym piśmie 24 stycznia 1834 roku. Pod redakcją Ujazdowskiego pismo miało charakter popularnego magazynu. Klemens Bąkowski przed 100 laty tak scharakteryzował „Rozmaitości Krakowskie”: „Zwyczajem ówczesnym zawierają drobne artykuły, jakie się redaktorowi nawinęły i anegdotyczne wypisy wiadomości zagranicznych, wreszcie wiadomości z dzisiejszej poczty o kilkunastu wierszach druku" ${ }^{144}$. Tenże historyk dostrzegł też „poważniejsze artykuły”.

Na czele numeru pierwszego umieścił Ujazdowski artykuł Teby miasto Górnego Egiptu według dzieła Dominique'a Vivanta Denona Voyage dans la Basse et la Haute Egypte, pendant les campagnes du général Bonaparte (Paris 1802, do 1829 roku dzieło to miało 4 wydania), francuskiego uczonego, który towarzyszył Napoleonowi w czasie wyprawy do Egiptu w 1798 roku. Obok zwięzłej informacji o ruinach starożytnego miasta napisano o zaborze elementów zabytkowych budowli i ich transporcie do Paryża. W tym samym numerze w rubryce „Wiadomość z dzisiejszej poczty" znalazło się doniesienie o przypłynięciu do Paryża kolumny ze świątyni w Tebach ${ }^{145}$. W następnych numerach zamieszczono artykuły: Towarzystwo Biblijne, podano najważniejsze informacje o działalności Brytyjskiego Towarzystwa Biblijnego i towarzystw biblijnych w różnych krajach. Resztę miejsca zajęło Drugie oblężenie Wiednia — opis wojny turecko-austriackiej w 1683 roku od jej początku do klęski najeźdźców pod Wiedniem ${ }^{146}$. Ciekawy artykuł w sposób popularny przedstawia historię, budowę i korzyści z Kolei żelaznej, w której siłą pociągową były konie. Dla mieszkańców Krakowa interesujący był artykuł o odnowionym w 1833 roku przez Senat Rządzący Krakowa towarzystwie strzelców krakowskich - Rys historyczny Szkoły Strzeleckiej w Krakowie oraz Wyszczególnienie przychodu [i rozchodu] Rzplitej Krakowskiej na r. 1833/4 przez Zgromadzenie Reprezentantów uchwalony... ${ }^{147}$. Sytuację Greków, Ormian i Żydów mieszkających w stolicy Turcji przedstawiono w artykule $O$ rozmaitych narodach w Carogrodzie. Z warszawskiej „Gazety Codziennej” został przejęty artykuł Wieś Lipki, który Ujazdowski dopełnił swymi uwagami uzupełniającymi. Ponieważ dotyczył on jego stron rodzinnych, uwagi te były bardzo szczegółowe, m.in. wskazywały na utrzymywanie się tamtejszych mieszkańców głównie z lasu („Gdyby nie las i grzybki, zginęłyby dawno Lipki”), który do nich nie na-

144 K. Bąkowski, Dziennikarstwo krakowskie do roku 1848, „Rocznik Krakowski” 8, 1906, S. 179 .

145 „Rozmaitości Krakowskie” 1834, nr 1, s. 1-3, 8.

146 Towarzystwo Biblijne, „Rozmaitości Krakowskie” 1834, nr 4, s. 25-26; Drugie oblężenie Wiednia przez Turków roku 1684, „Rozmaitości Krakowskie” 1834, nr 4, s. 26-32, na podstawie Dyariusza wyprawy Turka pod Wiedeń 1684 z włoskiego tłomaczony, Kraków 1786).

147 „Rozmaitości Krakowskie” 1834, nr 5, s. 33-36; nr 12, s. 89-92. 
leżał. Problemy tej wsi przedstawił już w „Pamiętniku Sandomierskim”148. Obok artykułów były bardziej zwięzłe informacje, z których czytelnicy dowiadywali się np. o austriackim mieście Linz, lamparcie, o wodociągu z czasów rzymskich w Segowii w Hiszpanii, o młynkach modlitewnych Kałmuków, o grobie Fausta Socyna w Lusławicach i dzwonie kościelnym z 1482 roku w Podegrodziu k. Starego Sącza itp. Wśród tych artykulików są też anegdoty, np. o Kazimierzu Sprawiedliwym w Sandomierzu, o przyjaźni byłego marszałka Francji Jeana Baptiste'a Bernadotte'a, który został królem Szwecji Karolem XIV, z dawnym jego podwładnym cieślą Thiébautem ${ }^{149}$ itp. Są też informacje o nowościach wydawniczych, np. obszerny prospekt na Pieśni Słowaków Karpackich, informacja o nowym tłumaczeniu na język francuski utworu Juliana Ursyna Niemcewicza ${ }^{150}$. Czytelnicy „Rozmaitości Krakowskich” dowiedzieli się o ukazaniu się w Legnicy książki o Dorocie, księżnej na Legnicy i Brzegu — książka ta ukazała się w Brzegu w 1830 roku $^{151}$. Ujazdowski w „Rozmaitościach” przedrukował też swój artykuł z 1827 roku Rzecz o guillotynie, a w krótkiej notatce podał wiadomości o Piotrze Żupniku, o którym zamieścił artykuł w „Pamiętniku Sandomierskim”152.

Do ciekawszych artykułów zamieszczonych w pierwszych numerach „Rozmaitości" należała Rozmowa potoczna Francuza z Angielka z rękopisu W. T. Jacquemont znalezionego w Bombaj (tłumaczył z francuskiego X.T.) — dialog, z którego wynika, że Angielka bardzo ceni sobie w małżeństwie bogactwo, pieniądze, natomiast jej rozmówca, Francuz, najwyżej stawia klejnot szlachecki. Napisał ją podróżnik francuski Victor Jacquemont, reprezentujący w Indiach Muzeum Historii Naturalnej w Paryżu. Zmarł on w Bombaju w 1832 roku w wieku 31 lat, a jego pisma zaczęto wydawać drukiem rok później153. Satyrą jest Rękopism nadestany ze stolicy jednej z nowo założonych Rzplitych Afrykańskich opowiadającą o osadzie założonej przez Brukowców, gdzie pozbyto się Szubrawców, którzy ich krytykowali. Dla Brukowców nie trud nauki był ważny, lecz zabawy, dobre

148 „Rozmaitości Krakowskie” 1834, nr 5, s. 38-40; nr 7, s. 49-53; Trzystoletnia sprawa, „Pamiętnik Sandomierski” 1, 1829, s. 416-417.

149 „Rozmaitości Krakowskie” 1834, nr 11, s. 82 (właściwie 83-84). Przyjaźń szwedzkiego króla i cieśli była tematem wodewilu pt. Kolega granego wówczas w Paryżu — zob. „Tygodnik Petersburski" 1834, nr 6, s. 37-38.

150 „Rozmaitości Krakowskie” 1834, nr 7, s. 56.

151 „Rozmaitości Krakowskie” 1834, nr 9, s. 69; Koch, Denkwürdigkeit aus d. Leben d. Herzogin Dorothea Sibylla von Liegnitz und Brieg, geborne Markgräffin von Brandenburg und ihrer Lei- und Hebamme Marg. Fuss. Wortlich aus Rothgebers V Gierths Haus- und Tagebuche mit e. Vorte, erlautert. Anmerk. und Beilagen, Brieg 1830.

152 „Rozmaitości Krakowskie” 1834, nr 3, s. 17-20; nr 10, s. 8. Artykuł o gilotynie ukazał się w „Rozmaitościach Warszawskich” 1827, nr 15, s. 113-116. Za „Tygodnikiem Petersburskim” (nr 7, s. 44) zamieścił Ujazdowski w „Rozmaitościach” (nr 9, s. 67-68) uwagi o cierpieniach skazańców traconych na gilotynie. O rękopismie Piotra Żupnika z Soli, „Pamiętnik Sandomierski” 2, 1830, s. $618-622$.

153 „Rozmaitości Krakowskie” 1834, nr 1, s. 3-6. 
jedzenie i unikanie „wszelkiej ciężkiej naukowości lub wiadomości, które tylko fizycznym i umysłowym wyrobnikom przystoją”. Ci zaś to „wymokłe i ogolone literackie i biurowe facjaty takie mające wejrzenia, jak gdyby dzisiaj dopiero ze Sto Michalskiego więzienia we Francji się wydobyły". Pod tekstem zamieszczono informację: „Za rzeczywistość oryginału [stoi] Selwester Gapowicz Mazepa”"154. Anegdoty na temat Sokratesa i fragment rozmowy G.G. Byrona przed podróżą do Grecji, gdzie spodziewał się umrzeć ${ }^{155}$, nie wyczerpują materiałów literackich. Wśród kilkunastu wierszy są epigramaty Marcjalisa, które przełożyli Z.N. i A.K. ${ }^{156}$ Objętością i starożytnością wyróżnia się wiersz z XVII wieku nieznanego autora Wieczny Boże, który Ujazdowski niesłusznie przypisał poecie z I połowy XVII wieku Olbrychtowi Karmanowskiemu ${ }^{157}$. Próbą utworu historycznoliterackiego jest artykuł Anakreont i Safo, w którym autor po krótkiej analizie twórczości greckich poetów sformułował dość ogólne oceny. Swe uwagi zakończył propozycją: „Czy nasz sąd o Safonie i Anakreoncie jest sprawiedliwy, znawcy oryginału niechaj ocenią a krytykę przyjmiemy z wdzięcznością, celem bowiem naukowej polemiki powinna być prawda"158. „Rozmaitości Krakowskie” informowały o śmierci Aleksandra Bronikowskiego, o odsłonięciu w Ferrarze pomnika Ariosta, o pracach Jana Kollara nad przekładami literatury polskiej na język czeski ${ }^{159}$ itp. Ciekawe są Przysłowia tureckie ${ }^{160}$. Pozytywną ocenę książki Józefa Jędrzeja Załuskiego Bibljoteka historyków, prawników i polityków, którą do druku przygotował Józef Muczkowski, przejęto z wydawanej w Halle „Allgemeine Literatur-Zeitung” (1833, nr 135). Ujazdowski w przypisie dodał: „Praca pana Muczkowskiego tyle razy cenę i uwielbienie znajdzie, ilekroć miłośnikom rzeczy krajowych jak nieuchronna skazówka przewodniczyć będzie; niech mu ta myśl przynajmniej nagradza podjęte staranie". Druga recenzja pochodząca z Krakowa oceniła modne wówczas noworoczniki. Wydanym na rok 1834 recenzent wytknął brak prac polskich artystów ilustratorów ${ }^{161}$.

Ujazdowski korzystał z materiałów z różnych czasopism: „Gazeta Lwowska” i jej dodatek tygodniowy „Rozmaitości”, spośród pism warszawskich potwierdzone są „Dziennik Powszechny” i „Gazeta Codzienna”, z terenu Rosji „Tygodnik Petersburski”; z czasopism w innych językach: „Časopis Českého Museum” z Pra-

154 „Rozmaitości Krakowskie” 1834, nr 2, s. 9-12.

155 Sokrates, „Rozmaitości Krakowskie” 1834, nr 11, s. 81-82; nr 13, s. 101-102; Rozmowy z Byronem, „Rozmaitości Krakowskie” 1834, nr 2, s. 14 (tekst przejęto z „Tygodnika Petersburskiego").

156 „Rozmaitości Krakowskie” 1834, nr 3, s. 24; nr 11, s. 88.

157 „Rozmaitości Krakowskie” 1834, nr 3, s. 23-24. Wiersz Ujazdowski wcześniej zamieścił w „Pamiętniku Sandomierskim” 2, 1830, s. 416-422.

158 „Rozmaitości Krakowskie” 1834, nr 13, s. 97-99.

159 „Rozmaitości Krakowskie” 1834, nr 10, s. 8; nr 11, s. 82 (właściwie 83); nr 13, s. 99 i 102.

160 „Rozmaitości Krakowskie” 1834, nr 12, s. 93-94.

161 „Rozmaitości Krakowskie” 1834, nr 6, s. 41-46; nr 9, s. 65-67. 
gi, „Militär-Wochenblatt” i „Jahrbücher für wissenschaftliche Kritik” z Berlina, „Österreichische militärische Zeitschrift" z Wiednia oraz wspomniana wyżej „Allgemeine Literatur-Zeitung” z Halle. Wykorzystał informacje z nieznanego Estreicherowi „Rocznika XIV Towarzystwa Biblijnego Poznańskiego”. Zapewniał też redaktor: „czytaliśmy już [...] rozprawy pod względem strategicznym nad bitwami pod Grochowem, [...] czytaliśmy historją kampanii Rossijskiej w r. 1831 wydaną w Petersburgu"162. Z jednego z berlińskich czasopism przejął Ujazdowski informację o spadku w Rosji w 1831 roku liczby nauczycieli i uczniów ${ }^{163}$.

Ujazdowski redagował „Rozmaitości Krakowskie” zaledwie przez kwartał, od początku stycznia do 30 marca 1834 roku — ukazało się wówczas tylko 13 numerów, każdy w objętości jednego arkusza. Od 1 kwietnia do 7 grudnia (nr 48) tego roku redagował tygodnik Konstanty Majeranowski pod zmienionym tytułem: „Rozmaitości”. Ten pięciomiesięczny okres (listopad 1833-marzec 1834) w dziejach „Gazety Krakowskiej” i „Rozmaitości Krakowskich” jest godny zauważenia przez historyków, szczególnie historyków prasy. Od 1 kwietnia 1834 roku zmienił się tytuł pisma na „Rozmaitości” i jego zawartość - stało się ono bardziej literackie i niezaangażowane politycznie. Nie tylko zmieniły się „Rozmaitości”, ale także „Gazeta Krakowska”, która od 1 kwietnia wprowadziła na swych łamach nowy dział „Część Literacka”, a pierwszym artykułem w tym dziale był Jakiemi powinny być dzienniki? Napisano w nim: „Niepodobna zaprzeczyć, że wolność druku jest w pewnym względzie królową, która miewa swój cierpki i słodki humor, swoich dworaków, ministrów, swój pałac i swoje nadużycia". Dzieje się tak dzięki „złym ustawom i zepsutym obyczajom”. Przykładów dostarczył opublikowany tydzień później artykuł Dziennikarstwo w Anglii. Z pisma angielskiego Metropolitan. W 1835 roku do „Gazety Krakowskiej” powróciła rubryka „Rozmaitości”164.

Ostatnią opublikowaną pracą naukową Ujazdowskiego jest Pomnik rycerstwa polskiego z wieku XV. Odkryty przez Tomasza Ujazdowskiego, niegdyś wydawce Pamiętnika Sandomierskiego, wydany w Krakowie w grudniu 1835 roku nakładem wydawcy. Ujazdowski, kończąc swój krótki Opis pomnika z XV wieku przedstawiajacego Jana de Ognasd [Jana z Ujazdu] wojewodę wołoskiego, starostę czchowskiego, zapewnił: ,przedstawiam pomnik i krótki opis”. O tym, że do jego tekstu była dołączona ilustracja, świadczy też opis bibliograficzny tego druku w Bibliografii Estreichera, gdzie w opisie podano objętość: ,arkusz 1 i rycina”"165.

162 „Rozmaitości Krakowskie” 1834, nr 4, s. 25-26; nr 13, s. 104.

163 „Rozmaitości Krakowskie” 1834, nr 9, s. 70; „Anzegeblatt zu den Jahrbücher für wissenschaftliche Kritik” (red. Societät für wissenschaftliche Kritik zu Berlin, Stuttgart und Tübingen), 1833, nr 9, szp. 1-2.

164 „Gazeta Krakowska” 1834, nr 75 (1 kwietnia), s. 297-298; nr 80-83; I. Homola, Prasa galicyjska w latach 1831-1864, [w:] Historia prasy polskiej, pod red. J. Łojka. [1], Prasa polska w latach 1661-1864, Warszawa 1976, s. 202-203.

165 K. Estreicher, Bibliografia polska XIX stulecia, t. 5, Kraków 1880, s. 594. Obecnie w bibliotekach najczęściej rycina jest przechowywana oddzielnie. 
Obraz ten, „na drzewie cyprysowem namalowany”, odkrył Ujazdowski „przypadkowo w domu obywatelskim”"166 w czasie „podróży naukowej” w 1835 roku. Było to epitafium Jana z Ujazdu herbu Śrzeniawa, właściwie Drużyna, wodza Wołochów i starosty czchowskiego, który zmarł w 1450 roku i został pochowany w kościele czchowskim. Tam też pierwotnie znajdował się obraz. Ujazdowski nie podał więcej szczegółów o miejscu znaleziska — obecnie malowidło znajduje się w zbiorach sztuki na Wawelu. Krakowski litograf i miedziorytnik, Feliks Lipnicki, wykonał litografię malowidła. Tekst Ujazdowskiego jest bardzo zwięzłym wprowadzeniem, w którym opisał, co przedstawia obraz, jego wielkość i podał odczytane przez siebie trzy różnej daty napisy w języku łacińskim. Nie wiadomo, kiedy Ujazdowski był w Czchowie - przed czy po zapoznaniu się z obrazem, ale poszukiwał w tamtejszym kościele starożytnych zabytków, jednak nie znalazł niczego

oprócz murów i chrzcielnicy kamiennej przedniej roboty owego wieku. Z gmachów starożytnych w Czchowie wznosi się jeszcze ułamek baszty zamku starościńskiego nad brzegami skalistymi Dunajca. Wstąpiwszy na ten wzniosły ułamek, przypominają się zaraz wieże niebotyczne zamków, dziś w gruzach się ukazujących, Zawrocie, Witkowice, Zakluk ${ }^{167}$, Melsztyn, Rożnów, Chebali$\mathrm{na}^{168}$, Zawada! Jakby na przekorę czasowi, ułamki Czchowskiego, Melsztyńskiego i Rożnowskiego zamków, wznoszą się pośród powabnych okolic Dunajca i jodłowych lasów!

Bezskutecznie szukał w kronikach polskich — zaczynając od Jana Długosza — i węgierskich wiadomości o Janie z Ujazdu. Na zakończenie wyraził nadzieję: „iż moje teraźniejsze usiłowania z równą uprzejmością będą przyjęte od światłej publiczności, jak i w latach upłynnionych".

\section{KSIĘGOZBIÓR UJAZDOWSKIEGO}

W Przedmowie wydawcy w pierwszym tomie „Pamiętnika Sandomierskiego” Ujazdowski napisał: „lubię dzieje ojczyste roztrząsać, które się w księgach, rękopisach i dawnych pomnikach zawierają, zatem więc idzie, że tak jak inni na zabawy ja w stosunku ich, mniej wprawdzie posiadając, na książki nie żałuję, bo poświęcam mój grosz dobrej sprawie". W czasie swych podróży, o których była już mowa, odwiedzał biblioteki, kancelarie kościelne, szkolne itp., gdzie znalezione książki lub dokumenty jego interesujące przeglądał, czynił notatki i odpisy oraz w miarę możliwości starał się je pozyskać do swych zbiorów. Kiedy książki uległy rozproszeniu, nie wiadomo. Najprawdopodobniej stało się to po śmierci właściciela.

166 Może w pałacu Henryka Lubomirskiego w Przeworsku.

167 Raczej Zakliczyn w powiecie tarnowskim.

168 Habalina albo Habelina, przysiółek wsi Wiatrowice, które są częścią wsi Tropie w powiecie sądeckim. 
Z księgozbioru Tomasza Ujazdowskiego znanych jest autorowi 10 starych druków i rękopisów znajdujących się w Bibliotece Narodowej i Bibliotece Uniwersyteckiej w Warszawie. Można się spodziewać, że dalsze badania proweniencyjne prowadzone przez bibliotekarzy w tych księgozbiorach powiększą tę liczbę. Brak takich badań w zbiorach książek z XIX wieku powoduje, że właściwie nic nie wiadomo o książkach Ujazdowskiego wydanych po 1800 roku. Ponadto ze sprawozdań Warszawskiego Towarzystwa Przyjaciół Nauk znane są tytuły dziewięciu książek przekazanych przez niego w darze w latach 1825-1830, a z „Pamiętnika Sandomierskiego" wiadomo, że posiadał sześć rękopisów. W ten sposób powstał spis druków i rękopisów z biblioteki Ujazdowskiego, zamieszczony w Aneksie.

Książki swoje Ujazdowski opatrywał pieczęcią: „Tomasz Ujazdowski” lub „Xiążka Tomasza Ujazdowskiego”, a obok niej zapisywał atramentem rok włączenia do swego zbioru. W dwóch przypadkach dodał raz „xiążka 708”, drugi raz tylko „2530”. Jest rzeczą oczywistą, że posiadał wszystkie swoje wydawnictwa („Pamiętnik Sandomierski”, „Tandeciarz” i Pomnik rycerstwa polskiego z wieku XV).

W 1820 roku Ujazdowski wprowadził do swojej biblioteki dwie książki pochodzące z księgozbioru klasztoru kanoników regularnych w Mstowie niedaleko Częstochowy. Mógł je pozyskać na miejscu w Mstowie, gdzie rok wcześniej klasztor uległ supresji, a Samuel Bogumił Linde zabrał książki do Biblioteki Publicznej przy Uniwersytecie Warszawskim i prawdopodobnie jakaś część klasztornego księgozbioru pozostała na miejscu. Może Ujazdowski, jako student Uniwersytetu Warszawskiego, dokonał wymiany książek z Biblioteką Publiczną, o czym brak informacji w zachowanych dokumentach ${ }^{169}$. Ze Śląska sprowadził rękopis największego dzieła Franciszka Jabłońskiego, Herby rycerstwa polskiego. Tam też nabył rękopis Kazimierza Malinowskiego Compendium Juris Polonici Usibus Polonorum applicatum, a w samym Wrocławiu A.R. Vertota Historye Rewolucyi Krolestwa Szwedzkiego y Duńskiego po polsku wyłożona (Kraków 1701). W 1826 roku zakupił kilkadziesiąt książek łacińskich, które ok. 1590 roku sprowadził Jacek lub Jakub, ale najprawdopodobniej bibliofil Jan Ponętowski ${ }^{170}$. O tym nabytku napisał:

W roku zeszłym nabyłem kilkadziesiąt książek w języku łacińskim; między temi znajdowało się 43 in folio w pergamin, w sposobie włoskim oprawnych. $Z$ tych jedną wziąłem dla przejrzenia (były to polityki Arystotelesowe w językach greckim i łacińskim przez Teodora Zuingera przy-

169 E. Bylinowa, Renesansowy księgozbiór Rodziny Strzemboszów, [w:] Księgozbiory szlacheckie XVI-XVIII wieku. Kolekcje historyczne, Warszawa 2004, s. 84-85.

170 Jan Ponętowski (ok. 1540-1598), w latach 1577-1587 opat w klasztorze norbertanów w Mnichovo Hradiště (obecnie część Ołomuńca) na Morawach; tam gromadził dzieła sztuki (obrazy, sztychy, gobeliny), książki — zob. L. Hajdukiewicz, Jan Ponętowski - opat hradyski, bibliofil i miłośnik sztuki. Materiały do życiorysu, „Roczniki Biblioteczne” 14, 1970, s. 524-525. 
pisane Xięciu Alexandrowi na Słucku Radziwiłłowi, z roku 1582, wydanie Bazylejskie ${ }^{171}$ ) i spostrzegłem w pośród okładzin pergaminowych, karty do grania na tekturę zamienione. Starałem się iak najostrożniey rozdzielić one, a oczyściwszy one z kleju rozpoznałem cztery figury.

Karty znalazł w 29 księgach z tego zakupu. Jego zdaniem były to drzeworyty tłoczone ok. 1580 roku i nieudolnie kolorowane. Jedna z nabytych wówczas książek miała zapisany rok oprawy: 1591. Sądził, że oprawiono je w Krzepicach ${ }^{172}$.

Ujazdowski nie tylko gromadził książki i dokumenty. Wiadomo, że posiadał także numizmaty, skoro darował ze swych zbiorów Towarzystwu Przyjaciół Nauk: pieniądz srebrny cesarza Antoninusza Piusa - przekazany przed 30 kwietnia 1827; pieniądz srebrny cesarza Hadriana — przekazany przed 30 kwietnia 1827; 2 trojaki polskie, miedziane z 1787 i 1791 roku — przekazane przed 4 grudnia 1827; pieniądz srebrny, gdański z roku 1533 Zygmunta I - przekazany przed 15 grudnia 1828 (2 września 1827); krzyżyk mosiężny — przekazany przed 30 kwietnia 1827; dwie pieczęcie rządowe z czasów Stanisława Augusta — przekazane przed 15 grudnia 1828 (2 września 1827$)^{173}$.

Z lektury „Pamiętnika Sandomierskiego” wynika, że Ujazdowski przekazywał do zbiorów Towarzystwa i Biblioteki Publicznej przy Uniwersytecie Warszawskim dokumenty i książki otrzymane od różnych osób, które przeznaczyły je dla tych insty tucji. List Walentego z Dębian Dębińskiego Kanclerza Koronnego do Generała Miechowitów użyczony Ujazdowskiemu przez Franciszka Bogdańskiego był przeznaczony dla Biblioteki Publicznej, która odbiór jego potwierdziła, umieszczając $\mathrm{w}$ prasie podziękowanie za otrzymany dar ${ }^{174}$. Prezesi Towarzystwa Przyjaciół Nauk, Stanisław Staszic i Julian Ursyn Niemcewicz, w swych sprawozdaniach przedstawianych na posiedzeniach publicznych wymieniali darowane przez Ujazdowskiego książki i inne przedmioty. Franciszek Siarczyński w Spisie darów dla Ossolineum dziękował Ujazdowskiemu za karty do gry znalezione przez niego w książkach nabytych w 1826 roku $^{175}$. Prawdopodobnie z inicjatywy Ujazdowskiego kaliski nauczyciel Jakub Lipski wykonał gipsową kopię płaskorzeźby z XV wieku z kościoła św. Mikołaja w Kaliszu przedstawiającą scenę

171 Arystoteles, Politicorum libri octo, Theodor Zwingeri argumentis [...] illustrati, Basileae 1582.

172 T. Ujazdowski, Karty polskie..., s. 87.

173 J.U. Niemcewicz, Zagajenie posiedzenia publicznego [...] dnia 30 kwietnia i 4 grudnia 1827, [...] 15 grudnia 1828, „Roczniki Warszawskiego Towarzystwa Przyjaciół Nauk” 20, 1828, s. $38-39,105$; t. 21,1830 , s. 133 . W nawiasach podano daty zapisania w spisie Ofiary do zbiorów osobliwości, AGAD, TPN, 93, s. 24, 42.

174 „Pamiętnik Sandomierski” 2, 1830, s. 91; „Kurier Warszawski” 1830, nr 21.

175 F. Siarczyński, Spis darów uczynionych dla księgozbioru publicznego imienia Ossolińskich oraz ich dawców, po ostatnim zdaniu sprawy w zeszycie drugim Czasopisma r. 1828, „Czasopism Naukowy Księgozbioru Publicznego Imienia Ossolińskich” 2, 1829, z. 1, s. 153. 
egzekucji gilotyną, którą przesłano Towarzystwu 1 kwietnia 1827 roku$^{176}$. Następną znacznie większą przesyłką dla Towarzystwa z Chęcin miała być rzeźba Baby opisanej w „Pamiętniku Sandomierskim”. Ujazdowski przekonał władze województwa krakowskiego, które zajęły się organizacją transportu rzeźby do Warszawy. Przygotowany w Chęcinach przez Szamota artykuł o Babie Ujazdowski przekazał Towarzystwu, a poszerzony przez siebie zamieścił w „Pamiętniku Sandomierskim”. Ostatecznie rzeźby Baby i Niemca pozostały w Chęcinach ${ }^{177}$. W przypadku przekazania Towarzystwu płaskorzeźby z gilotyną i Baby Ujazdowski był inicjatorem, wciągając do tego ludzi miejscowych. W przypadku drugiej rzeźby musiał przekonać do tej sprawy także władze województwa krakowskiego. Można przypuszczać, że Ujazdowski swymi działaniami starał się pozyskać przychylność członków Towarzystwa Przyjaciół Nauk, by w przyszłości uzyskać pełnoprawne uczestnictwo w jego pracach. Nie doczekał się tego.

$$
* * *
$$

Ujazdowski w czasie swych podróży mało interesował się krajobrazem. W swych relacjach, artykułach starał się pisać tylko o interesujących zabytkach. W poszukiwaniach wykazywał się dużą dociekliwością, jak choćby w Seceminie, gdzie w tamtejszym kościele, obejrzawszy kamienną rzeźbę, wysłuchał objaśnień miejscowego proboszcza i innych osób. Ujazdowski starał się poznać nowe zabytki architektury, plastyki, archeologii, ich historię. W czasie podróży dawało mu satysfakcję poznawanie nowych zabytków, ich historii i literatury na ich temat. Do legend na tematy poznawanych kościołów, zamków itp. odnosił się nieufnie. Nie można też zapomnieć o jego zasługach dla etnografii polskiej: w „Pamiętniku Sandomierskim” ukazał się przecież „,pierwszy opis ubioru Kielczan i wzmianka o wierzeniach ludu w okolicach Chęcin (upiór, strzyga, zmora, płaczka i czarownica)" ${ }^{178}$. Z winy wypadków historycznych Ujazdowski pojawił

176 T. Ujazdowski do J.U. Niemcewicza 1 kwietnia 1827 roku z Kalisza, prawdopodobnie list podpisał również drugi nauczyciel kaliski Jakub Lipski. Oryginał płaskorzeźby przekazano do Puław, zob. A. Patkowski, op. cit., s. 219. O tym zabytku Ujazdowski napisał artykuł.

177 J.U. Niemcewicz, Zagajenie posiedzenia publicznego Towarzystwa Królewskiego Warszawskiego Przyjaciót Nauk dnia 30 kwietnia 1829 i Zagajenie sessyi publiczney Towarzystwa Królewskiego Przyjaciół Nauk w dniu 15 grudnia 1829, „Roczniki Towarzystwa Przyjaciół Nauk” 21, 1830, s. 123-124, 217. Lelewel czytał swoje uwagi na posiedzeniu Działu Nauk Towarzystwa w dniu 17 października 1828 roku, AGAD, TPN, 28b, s. 186-187. Por. też „Gazeta Polska” 1828, nr 275, s. 1097; M. Baliński, T. Lipiński, Starożytna Polska pod względem historycznym, jeograficznym i statystycznym opisana, t. 2, cz. 1, Warszawa 1844, s. 381-382.

178 M. Walicki, Sprawa inwentaryzacji zabytków w dobie Królestwa Polskiego (1827-1862), Warszawa 1931, s. 44; B. Erber, Zarys stanu badań etnograficznych w województwie kieleckim, „Rocznik Muzeum Świętokrzyskiego” 1, 1964, s. 334. 
się w polskim piśmiennictwie naukowym epizodycznie, przygodnie, jako autor stosujący opisową inwentaryzację dzieł sztuki w Polsce, jednak zasługi jego dla polskiej kultury i nauki są niepodważalne.

\section{ANEKS}

SPIS DRUKÓW I RĘKOPISÓW Z BIBLIOTEKI TOMASZA UJAZDOWSKIEGO

I. Książki, rękopisy i dokumenty wymienione w „Pamiętniku Sandomierskim" jako własność Ujazdowskiego:

1. Rękopis Piotra Żupnika z 1459 roku (zob. „Pamiętnik Sandomierski” (dalej: PSan) 2, s. 618-622).

2. Fragment pozwu w sprawie kościołów w Piewniku i Wierzbnie (zob. PSan 1, s. 379).

3. Franciszek Jabłoński, Herby rycerstwa Polskiego, rękopis, sprowadzony ze Śląska (zob. PSan 1, s. 249-353).

4. Kazimierz Malinowski, Compendium Juris Polonici Usibus Polonorum applicatum, rękopis, kupiony na Śląsku (zob. PSan 1, s. 2-39).

5. Piękne iest koło rycerskie, odpis tekstu z rękopisu znalezionego w Bibliotece Pojezuickiej w Cieszynie i teksty nadesłane na apel w prasie (zob. PSan 2, s. 109-114).

6. Odpis listu cesarza Leopolda do polskiego króla Jana III Sobieskiego z 1689 roku, oryginał w Bibliotece XX. Pijarów w Piotrkowie Trybunalskim (zob. PSan 2, s. 220-222).

7. Aubert René Vertot, Historya Rewolucyi Krolestwa Szwedzkiego y Duńskiego po polsku wytożona przez Jana Potulickiego (prawdopodobnie: Warszawa 1701) (zob. PSan 2, s. 51).

II. Książka wymieniona w: T. Ujazdowski, Karty polskie do gry, „Monitor Warszawski" 1827, nr 18, s. 87:

8. Arystoteles, Politicorum libri octo, Theodor Zwingeri argumentis [...] illustrati, Basileae 1582.

III. Książki, rękopis i litografia znajdujące się w Bibliotece Narodowej w Warszawie:

9. Jakub Chrząstowski, Polonia geographice quo ad originem, situm et provincias, historice quo ad paces et balla regum, polityce quo ad statum Reipublicae rethoribus Collegii Pznaniensis Societatis Iesu anno Domini 1690, rękopis, łac. — „Xiążka Tomasza Ujazdowskiego 1823” — sygn. BOZ 801.

10. Jan Wuchaliusz, Vivificae passionis Christ historica explana tio cum doctissima applicatione ad utriusq[ue] testament, Kraków 1538, sygn. SD XVI.O.19. 
11. Piotr Skarga, Bractwo miłosierdzia w Krakowie v s. Barbary zaczęte roku Pańskiego 1584 miesiaca Octobra, do którego aby Pan Bóg serca ludzkie wzbudzić raczyt [...], któmu przydane sa tegoż bractwa powinnośći y porzadki, y Czytania z Pisma Ś., z doktorów, y z Zywotów swiętych o miłosierdziu y iatmużnie [...], Kraków 1598, sygn. SD XVI.Qu.51.

12. Societas S. Annae aviae maternae Christi Servatoris Nostr in Polonia sub rege Stephano et Iagiellonia regina, instituta M.D.LXXVIII [...], Zamość 1599, sygn. SD XVI.Qu.577.

13. Nicolai Ioannes, De luctu Graecorum, [Marpurgiae?, po 6 września 1696], sygn. SD XVII.1.5271.

14. Marcus Tullius Cycero, [...] Mannuciorum commentariis illustratus antiquae que lectioni restitutus [pod red. Aldusa Manutiusa iuniora], t. 1-10, Venetiis 1583, Ujazd 1820, sygn. XVI. F.234.

15. Marcus Tullius Cycero, In apostoles M. Tulli Ciceronis quae familiares vocantur [...] Venetiis 1583 — „xiążka Tomasza Ujazdowskiego 1820” — sygn. XVI F.1667.

16. Litografia epitafium Jana z Ujazdu, wykonana przez Feliksa Lipnickiego, Zbiory Grafiki Biblioteki Narodowej, pieczęć: Tomasz Ujazdowski.

IV. Książki znajdujące się w Bibliotece Uniwersytetu Warszawskiego:

17. Marcin Kromer, O sprawach, dzieiach y wszystkich inszych potocznościach koronnych polskich; ksiag XXX przez Marcina Błażowskiego z Błażowa; wyraźnie na polski ięzyk przettumaczone, przydatkami y dowodami niektóremi ponieką utwierdzone y własnym onegoż kosztem z druku na świat podane, Kraków 1611, Ujazd 1824 i 1826, sygn. 28.20.3.694.

18. Piotr Hiacynt Pruszcz, Forteca duchowna Królestwa Polskiego; Z żywotów świętych tak iuż kanonizowanych y Beatyfikowanych, iako też światobliwie żyiacych Patronów Polskich [...] Kraków 1662, Ujazd 1826 z Kielc, sygn. Sd 713.1886 .

19. Joannes Tucholiensis Cervus, Farragitis actionum iuris civilis, et provincialis saxonici, municipalisq; Maydeburgensis [!] et iuris polonici libri septem, Zamość 1607, Ujazd 18[28] —,xiążka 708” — sygn. Sd. 713.2.

V. Książki, rękopis i dokument przekazane przez T. Ujazdowskiego Towarzystwu Przyjaciół Nauk w Warszawie:

20. Nicolaus de Lyra, Quarta pars Lyrae: Libri totius novi testamenti cum postilis [...] Kopenhaga 1497, przekazana przed 20 stycznia $1826^{179}$.

179 S. Staszic, Zdanie sprawy o pracach Towarzystwa [...] z ostatnich lat czterech 1821, 1822, 1823, 1824 [...] w dniu 20 stycznia 1826, „Roczniki Warszawskiego Towarzystwa Przyjaciół Nauk” 19,1827, s. 36. 
21. [Biblia. Stary i Nowy Testament] w jęz. łac., ,z pierwszych druków”, przekazana przed 30 kwietnia 1827.

22. Dzieło w języku angielskim w materii kościoła i religii protestanckiej, „dwie księgi”, przekazane przed 30 kwietnia 1827.

23. M. Andrea Lubelczyk Bochnen[sis], Bellum Theologicum ex armamantavio omnipotentis adversum Turcas instructum, Cracoviae apud Viduam Ungeeri 1545, przekazane przed 4 grudnia 1827 (15 listopada 27).

24. Biblia Latina, Basil 1491, Jo. Froben de Hammelbruck, przekazana przed 4 grudnia 1827 (15 listopada 27).

25. Barthol[ommeo] Platina, Historia de vitis pontificum Romanorum a D. N. Jesu Christo usque ad Paulum II Venetum Papam, Coloniae 1574, przekazane razem ze znalezionymi w okładkach kartami do gry przed 4 maja 1828.

26. Jan Paweł Woronicz, „rękopism historyczny miasta Liwa” z 1786 roku, przekazany przed grudniem 1829 .

27. Gabriel Taszycki, Projekt wiecznego bezkrólewia, 1790, przekazany przed grudniem 1829 (1829).

28. Dyariusz wyprawy Turka pod Wiedeń 1684, z włoskiego tłomaczony, Kraków 1786, przekazany przed grudniem 1829 (1829).

29. Przywilej Władysława IV pasowania na rycerza Andrzeja Bełzy, przekazany przed 30 kwietnia $1830^{180}$.

MARIAN PTASZYK

TOMASZ UJAZDOWSKI (1796-1836) - A TEACHER, JOURNALIST, PUBLISHER, “ANTIQUARIAN”, LOVER OF BOOKS AND ANTIQUITIES, POLITICAL ACTIVIST

Summary

Tomasz Ujazdowski was born in 1796 in Vilnius. In 1812 he graduated from a school in Węgrów. The need to become financially independent prompted him to join the Piarist Order in Opole Lubelskie, where he took his perpetual vows. After completing his studies in Opole and Warsaw in 1817, he began to work as a teacher in Piarist-run schools. In 1819 he began his efforts to have his vows annulled. Despite the consent of his order's authorities, we was not released. He started a family. His longest stint as a teacher was in the regional school in Kielce (1822-1826), from where he was transferred to the regional school in Kalisz. In the summer of 1827 he was dismissed and excluded from the teaching profession. In 1828-1830 we worked in the Public Library at the University of Warsaw. During the November Uprising he was active in the Patriotic Society.

180 J.U. Niemcewicz, Zagajenie posiedzenia publicznego Towarzystwa Królewskiego Przyjaciót Nauk [...] dnia 30 kwietnia 1827, [...] 4 grudnia 1827, [...] 4 maja 1828, [...] 30 kwietnia 1830, „Roczniki Warszawskiego Towarzystwa Przyjaciół Nauk” 20, 1828, s. 35, 107; t. 21, s. 19; t. 30, s. 154; „Gazeta Polska” 1829, nr 333; „Gazeta Warszawska” 1830. W nawiasach podano daty zapisania w spisie Ofiary do Biblioteki [TPN], AGAD, TPN, 73, s. 19, 27. 
In 1826 he began to publish short articles in the Warsaw press about Polish monuments he encountered during his travels. He continued writing about them in Pamiętnik Sandomierski, a quarterly he published (1829-1830). He also included there old literary works as well as documents and articles concerning the regions of Podlasie, Sandomierz, Kraków and Kalisz. During the uprising he published a satirical magazine, Tandeciarz, where he fiercely denounced traitors and those reluctant to fight against the partitioner. He used contemporary and old works, particularly those from the last years of the Polish-Lithuanian Commonwealth.

After the uprising he moved to Kraków, where he was most likely involved in illegal patriotic activities. In 1836 he was deported to Trieste, where he died.

KEY WORDS: Tomasz Ujazdowski, Pamiętnik Sandomierski, Tandeciarz, Rozmaitości Krakowskie, collecting, bibliophile, folklorism, journalism 